\title{
Methodology and procedure of business impact analysis for improving port logistics business continuity management
}

\author{
Felipe Caselli Benavente ${ }^{1}$, Mauricio Reyes Gallardo ${ }^{1}$ Mario Beale Esquivel ${ }^{1}$, Yasuhiro \\ Akakura $^{2}$ and Kenji Ono ${ }^{2}$
}

Received: 31/01/2015 / Accepted: 03/03/2016 / Published: 17/06/2016

\begin{abstract}
This paper offers an overall view of applying business impact analysis (BIA) to prepare business continuity plans (BCP) for port logistics based on the joint research project to create a tsunami resilient society undertaken by researchers from Chile and Japan. Authors review Chilean socio-economic circumstances and currently developed disaster responding system in the national and regional context, and identify significance and social request of maintaining the continuity of port logistics functions in association with integrated risk management of tsunami disaster. The authors place particular emphasis on the possible engagement of BIA for improving efficiency and effectiveness of port logistics BCP. The authors propose an appropriate procedure, techniques and tools for BIA implementation in this regard, and demonstrate them as a practical example of BIA implementation in the port of Iquique, Chile. Finally, some recommendations and suggestions are provided for the development of future work, as well as the necessary development of policies.
\end{abstract}

Keywords Tsunami resilient society; Business continuity plan; Business impact analysis; Integrated disaster risk management; Business continuity management.

\section{INTRODUCTION}

Since the Central Chile earthquake and tsunami in 2010, and the Great East Japan Earthquake in 2011, both countries have shared a growing concern of large scale tsunami disasters destroying the national socio-economy and coastal communities. Therefore, an international joint research project, namely SATREPS Chile (Science and Technology Research Partnership for Sustainable Development between

\footnotetext{
${ }^{1}$ Escuela de Ingeniería Civil Oceánica, Universidad de Valparaíso, Valparaíso, Chile, felipe.caselli@uv.cl / mauricio.reyes@uv.cl / mario.beale@uv.cl

${ }^{2}$ Disaster prevention Research Institute, Kyoto University, Kyoto, Japan, akakura.yasuhiro.6n@kyoto-u.ac.jp / kenji.ono.5z@kyoto-u.ac.jp
} 
Japan and Chile) was initiated.

The project includes, as an overarching approach to create tsunami resilient communities, a research objective of preparing business continuity plans (BCP) in the Chilean ports to facilitate minimizing aftermath negative impact of the disaster on the socio-economy, as well as promptly mobilizing port functions for emergency relief logistics (ERL).

The port of Iquique, located in the region of Tarapacá, was selected as a pilot study site to develop the necessary methodology to properly prepare a Chilean port BCP guideline. A consulting body, comprising port community members from Iquique, was set up in the port for undertaking a series of intensive discussions on the possible procedures and techniques needed for BCP preparation. One of the particular findings of this research include the significance of business impact analysis (BIA) in line with requirements for the development of a business continuity management system (BCMS), as stated in ISO22301 (ISO 2012). Necessary procedures and techniques for implementing the analysis in a transparent and traceable manner such as business flow analysis techniques and mobilization of worksheets suggested by Ono et al. (2014) were also discussed and their validity confirmed by the consultation meeting.

In view of this, the authors review first in this paper the national and regional emergency response system in Chile. The natural hazards and disaster risk which the country faces are also discussed. To meet the requirements for securing port logistics functions, integrated risk management of ports is needed. The authors consider that this can be achieved through the implementation of a comprehensive BIA. An appropriate procedure, techniques and tools for BIA implementation is proposed in this regard. Recommendations on the necessary policy development for facilitating proper inclusion of BIA and prompt preparation of BCP in the Chilean ports are provided accordingly.

\section{ECONOMY AND PORT LOGISTICS IN CHILE}

\subsection{National and regional economy in Chile}

\subsubsection{Characterization of the economic environment}

Since the mid-80s, Chile has defined its development strategy through exports growth (Agosin 1999; Bergoeing et al. 2011). As a result, the exports in 1985, 2000 and 2013, reached US\$ 3,804 million, US\$ 18,158 million, and US\$ 77,367.5 million respectively. These numbers show a significant sustained growth over the last 35 years (Ministerio de Relaciones Exteriores 2009). The export growth in Chile is most certainly accompanied by increasing importance of port infrastructure. In fact nowadays approximately $95 \%$ of the international trade happens through ports (CAMPORT 2013). The relation between the Chilean economy and its international trade was seen in 2009 after a sharp decline in exports. This caused deterioration in expectations for economic growth, employment and income; eventually causing a fall in GDP in 2009 over 2008 (CEPAL 2010). Therefore, it can be assumed that a disruption in the operation of ports could generate adverse impacts on the national economy.

\subsubsection{Economic situation in the north of Chile}

The GDP of the region of Tarapacá in 2010 represented 3.4\% of total GDP of the country (INE 2010). The economy of the region is mainly based on extraction, i.e. mining and fishing industries. However, trade is very important because there is the passage of products to northern countries (especially Peru, Bolivia and Brazil), through a highway network known as the oceanic corridor.

ZOFRI (Tax Free Zone of Iquique) has led to commercial development. There are 1,900 companies, with great impact on commerce and regional employment. The labor force in Iquique reached 87,000 people, of which 40\% were related to ZOFRI (Banco Central de Chile n.d., ZOFRI 2012). 
However, 43\% of regional GDP is explained by mining. Projections for the regional mining sector for 2012-2020, indicate it could reach US\$67,000 million of investment. Projections of mining production indicate that by 2020 fine copper production could reach 7.5 million tons, of which $74 \%$ will come from the Upper North ${ }^{3}$.

Tourism is also very important in Northern Chile. It has one of the best developed tourism industry in the country. In fact, hotels, restaurants and trade represent $30.68 \%$ of regional GDP.

With all that, the port of Iquique has faced a significant increase in demand, about $103 \%$ in 11 years (since 2000) in terms of port cargo. Port cargo of Iquique is projected to reach 5.6 million tons in 2015 (Banco Central de Chile 2010).

\subsection{Risk appraisal for the coastal area in Chile}

Since there are several conceptualizations of risk in several fields, a clear definition is needed. In this study, risk is considered as the product of probability of hazard occurrence and its impact, which are functions of vulnerability and exposure. These mathematical relations are not easy to compute, and generally require qualitative approaches to complement the scarce quantitative evidence.

For conceptual order, this appraisal will be disaggregated in terms of hazard and vulnerabilities.

\subsubsection{Earthquake and Tsunami Hazards for the coastal area in Chile}

Chile has a particular position and orientation that makes it prone to be affected by the tectonic plate's behavior: The country stretches from north to south between the volcano line of the Andes Mountains and the Pacific Ocean, and thus parallel to the subduction trench in almost its whole extension. So, Chile is located just over the zone where the Nazca and South American plates converge. Since 1562, historical data shows that more than 31 near-field tsunamis have ravaged the coasts of Chile, even producing the devastation of entire cities, like Arica in 1604 and Concepción in 1751 (Winckler et al. 2010). Taking into account the paleo-geological data, it appears that some giant tsunami show a larger recurrence: thus introducing a shadow of uncertainty over the statistical approaches for earthquake occurrence (Goldfinger et al. 2013). Figure 1 shows the tectonic configuration of the southeast Pacific Ocean.

\footnotetext{
${ }^{3}$ Area that includes the regions of: Arica and Parinacota, Tarapacá and Antofagasta, plus the northern half of Atacama.
} 


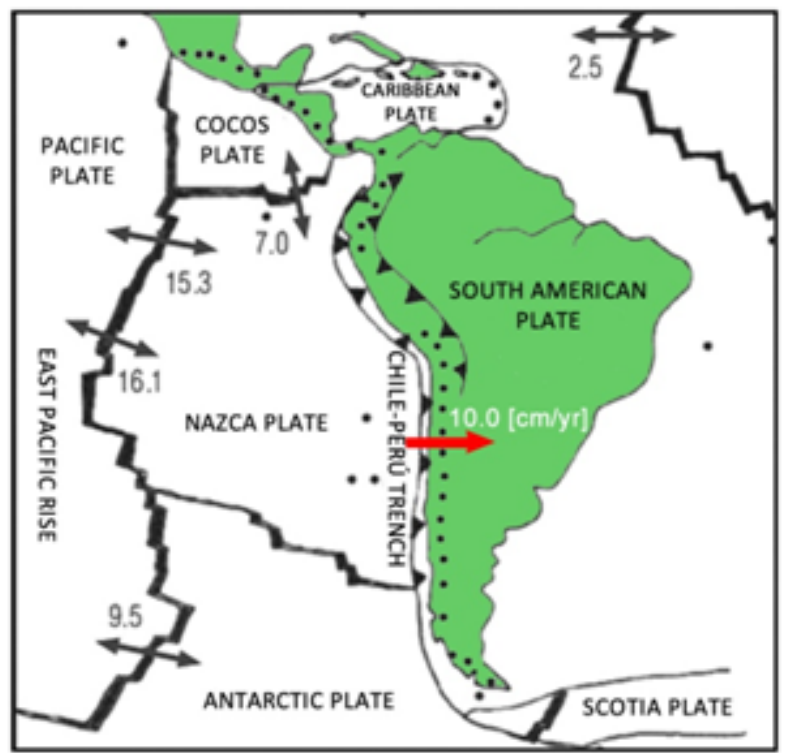

Figure 1 Tectonics configuration of the southeast Pacific Ocean. Active volcanoes represented with black circles (modified from Winckler et al. 2010)

The historical record indicates that more than 110 earthquakes with a magnitude greater than 7.0 have occurred since the year 1570 CE (Winckler et al. 2010). From these documented earthquakes, 78\% did not generate destructive tsunami, and only $11 \%$ generated highly destructive tsunami. Some locations show recurrence of tsunami impact, and several towns had even been moved from their original sites to safer locations (Reyes and Miura 2013).

Some of the historical descriptions include relevant information about tsunami, even justifying the cities' reposition because of tsunami inundations (Lomnitz 1970). There is little recurrence for earthquakes with inland epicenter and rupture zone. Whatsoever, the rupture zone is usually underwater, hence the majority of earthquakes in Chile meet the conditions of being tsunamigenic, even if only a few of them generate destructive tsunamis. Nonetheless, there is a permanent risk of tsunami generation, therefore tsunami generation scenarios must always be considered in the coastal regions of the country.

The statistical behavior of earthquakes and tsunamis show some tendency in very specific parts of the country. Notwithstanding, it is not possible to generate forecast information from that. For seismic design, the building code includes an acceleration spectrum that has been prepared on the base of historical earthquakes. After the earthquake of February $27^{\text {th }}, 2010$, some aspects of local seismicity and soil related risks has been introduced for improvement of the code. In the case of tsunami, just some supposition of tsunamigenic zones based on historical data are the usual input for estimation of inundation maps. All the biggest coastal cities have inundation maps developed by the Hydrographic and Oceanographic Service of the Navy (SHOA). The precision is not sufficient however for detailed hazard estimation, and have been used only to define evacuation zones and procedures, under very conservative criteria (Reyes and Miura 2013). Additionally, the introduction of tsunami resistant design of structures is not yet fully developed; however, there is an official standard recommended for that purpose since 2013.

\subsubsection{Northern Chile}

The northern part of Chile cannot be evaluated in the same way as the rest of the country, due to the particular conditions of its historical development. Although evidence is scarce, several scientific studies had identified the existence of a seismic gap in northern Chile, with at least the capacity of generating an earthquake similar to the 1877 event, possibly with energy of Mw 8.6 - 8.8. However, the conditions 
have changed after the M8.2 earthquake occurred on April $1^{\text {st }}$, 2014. According to Hayes et al. (2014), the particular characteristics of that earthquake show a constraint in size and spatial extent of rupture, thus parts of the seismic gap remain locked. Thus, it is possible to expect future megathrust earthquakes to the south or to the north of the April $1^{\text {st }}$ event's rupture zone (Hayes et al. 2014). Regarding the confidence in earthquake forecasting along the subduction zone in front of Chile, Hayes et al. highlighted and compared the fore and aftershock's behavior of the April $1^{\text {st }} 2014$ earthquake and the February $27^{\text {th }} 2010$ earthquake, showing the difficulty of earthquake prediction in Chile (Hayes et al. 2014).

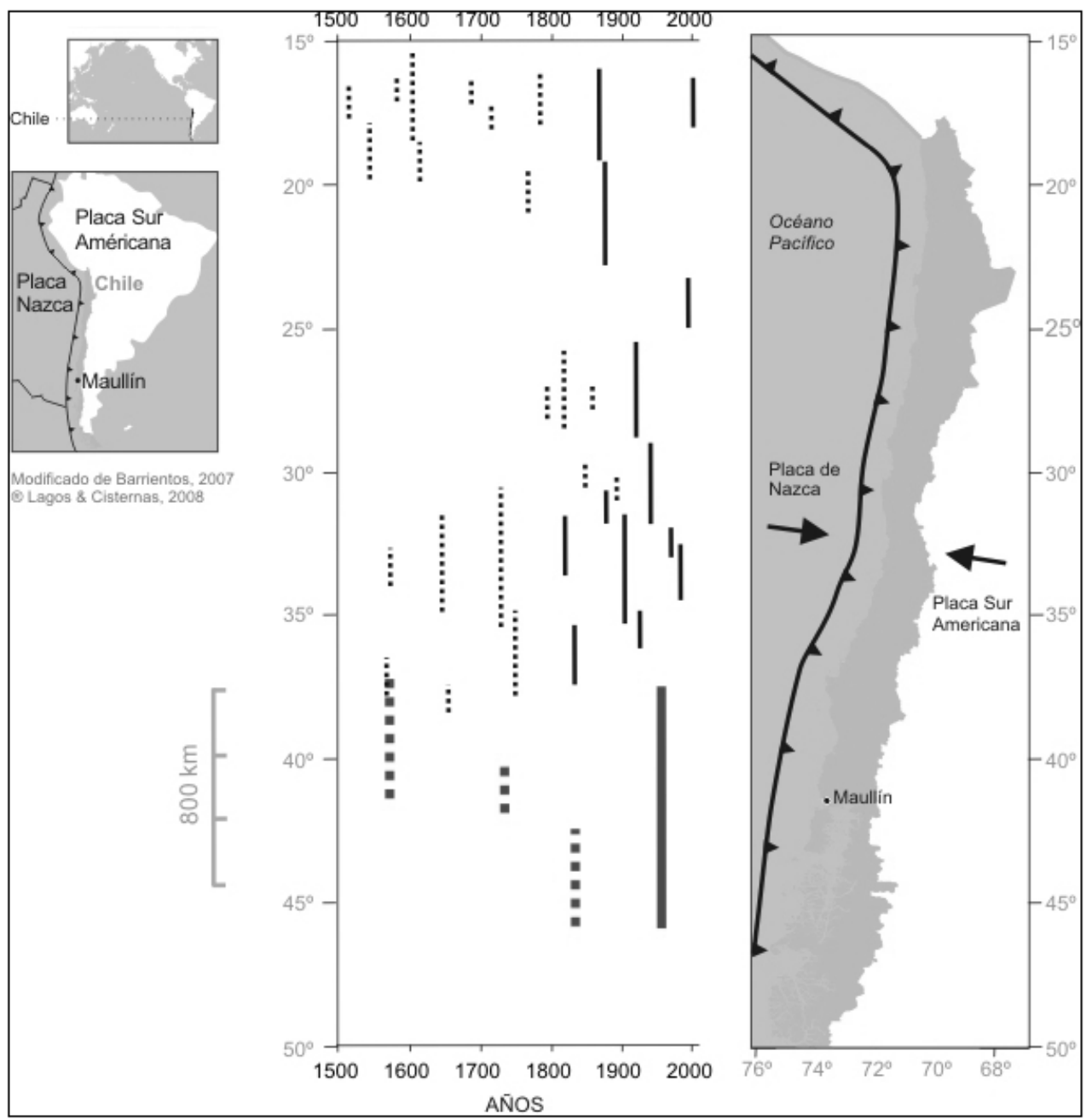

Figure 2 Historical earthquakes in Chile (modified from Winckler et al. 2010)

On the other hand, the April $1^{\text {st }} 2014$ earthquake generated a small tsunami with limited impact such as damage to some fishing boats, fishing equipment and materials, and the strand of a tug boat in Iquique port. However, some tsunami inversion studies are showing that there is a deficit of tsunamigenic slip at the western part of the South American plate along the seismic gap (Chao et al. 2014). So, with the available information on seismicity and tsunami generation in northern Chile it is not immediately possible to discount the possibility of megathrust earthquakes of Mw 9.0 or higher with destructive tsunamis. The occurrence of tsunami earthquakes must also be considered a possibility. 


\subsection{Emergency response system in Chile}

\subsubsection{Disaster risk analysis in Chile}

After the large earthquake and tsunami of $27^{\text {th }}$ February 2010 (herein referred to as 27F), Chile has been the subject of various studies towards the improvement of its natural disasters management system. The country is prone to almost all natural hazards possible, with the exception of hurricanes. Among the disasters that have occurred in Chile during the last century, the largest damages in term of casualties and economic losses were due to earthquakes (PNUD 2012a).

Maybe the most relevant and complete diagnostic study was undertaken by the United Nations Development Program (PNUD 2012b), reaching to a very good overview of Chile's performance and capacities in regard to natural disaster management. A number of issues are noted in the report, from which the following are considered more relevant for this research:

a. The entire country is susceptible to some kind of natural threat.

b. The risks due to these threats are increased, because the methods for their identification, analysis, evaluation and data availability were not sufficiently developed in Chile.

c. The risks due to natural disasters might be amplified, because the knowledge about vulnerabilities of communities, infrastructure and systems were not sufficiently developed in Chile.

d. There are risk management strategies in Chile that are either on course or in the planning stages, with favorable conditions in the coordination of personnel, initiatives and institutions for improving the situation.

e. The absence and/or difficult access to relevant and up-to-date information and utilities for disaster management, including initiatives, tools and past experience, is a limitation for risk management.

f. In terms of indicators, the country has sufficient financial resources to invest in the prevention and reduction of risks, with good levels of social expenditure, and adequate infrastructure.

The regulatory and institutional framework in Chile for disaster risk management has been developed and consolidated after each event. Also it should be noted that the large earthquake and tsunami that hit Valdivia in 1960 was the basis for the creation of the National Office of Emergency of the Ministry of Interior (ONEMI), and after 27F resulted in the proposition of the new National System of Emergency and Civil Protection, and the National Agency of Civil Protection, both currently in discussion in Parliament. ONEMI is the institution in charge of disaster management and has the following strategic objectives:

1) Strengthen, develop and coordinate the State's management in a crisis, through the technical assistance to sectorial bodies, as well as to regional, provincial and community teams.

2) Generate, foster and advise authorities and personnel from the different administrative levels of the country and community, in aspects related to risk management, early warning and emergency management, in order to upgrade the community with more and better conditions for protection and security.

3) Develop and disseminate methodologies, programs, studies and technical reports concerning vulnerability factors to different hazards, establishing guidelines for continuous improvement in the field of mitigation, prevention and preparedness, through projects and coordination with scientific and technical agencies.

The National System of Emergency and Civil Protection propose a series of decentralized bodies, created either from the public or private sector. The objectives of this system are to promote and implement actions in the prevention and relief of active or potential emergencies that may result in collective damage to people, property or the environment (PNUD 2012a). 


\subsubsection{Standard procedure for regional and local level risk management}

At regional level, the standard procedure corresponds to the system of national regulations being adapted for regional context through the Regional Emergencies Response Plan (ONEMI 2012). It is managed by the ONEMI regional office, with the remit outlined above. Response plans are mainly focused on emergency management (ONEMI 2012).

Emergency management at the local level is the responsibility of each municipality. Since 2011 there has been a Communal Response Plan, developed by the Municipality of Iquique, which outlines hypothetical disaster scenarios and the administrative measures to be put into effect in these emergencies (I. Municipalidad de Iquique 2011). The concept of risk, however, is not well defined, and is often mistaken for hazard.

\subsubsection{Institutional aspects}

Risk management in Chile is a specialized and, to some extent, an exclusive activity, without the effective participation of community organizations in terms of analysis and decision-making processes (PNUD 2012a).

One weakness of the risk management system in Chile is the lack of coordination between the institutions. This is worsening by the lack of preventive measures or preparation in society as a whole (PNUD 2012b). For national or regional governmental institutions the administrative structure is clear and robust, but for local government and administrative bodies, management capacities result in problems due to centralism and poor communication during emergencies (PNUD 2012a). ONEMI has made efforts to coordinate the work of NGOs and volunteers during emergencies and important investments have been made by the government during the last 3 years. Nowadays the functionality and organization have been notoriously improved.

Another relevant issue is the loss of the government controls because of privatization of some public services. Usually the government is not aware of the levels of risk and preventive measures undertaken by private entities until a crisis has already evolved (PNUD 2012a). This has been partially improved through several measures at national levels.

\subsubsection{Case study: the earthquake and tsunami of February 27th, 2010.}

PNUD conducted a survey in the town of Talcahuano, one of the biggest and most severely affected urban areas in the disaster zone of 27F. The conclusions of the survey were stated with reference to six dimensions: basic services, social, habitat, livelihood, connectivity and infrastructural, and governance (PNUD 2012b).According to the cited report, the disaster of 27F demonstrated a massive lack of preparation and risk management at all levels, which went from central government down to local communities, essentially involving the whole of Chilean society.

\subsubsection{Case study: the earthquake and tsunami of April 1st, 2014.}

This earthquake tested all the accumulated experience after the $27 \mathrm{~F}$ earthquake. Northern Chile has a particular context, in terms of culture and infrastructure, which determined certain aspects of the disaster. For instance, the earthquake was not large if measured by the number of people affected. However, it can be considered large when considering losses due to impacts on infrastructure.

The particular condition of foreshocks and aftershocks was very relevant for people's behavior and for infrastructure. Several evacuation actions, due to the main shock and some aftershocks, were well conducted and people showed a good preparation.

The port of Iquique was partially damaged, and it was in parallel to the BCP studies undertaken by the authors and the port headquarters, and benefits from that were observed. 


\section{BIA CONSIDERATION IN THE PORT-SUBSECTOR}

Since earthquakes and tsunamis are a permanent hazard for ports, hence they represent a risk for the economy. This section introduced some considerations to be taken in BIA for the port industries.

\subsection{Objectives and importance of BIA}

BIA is, as indicated by ISO 22301, one of key elements for successful business continuity management (BCM), which enables ports to fully understand its context and, therefore, decrease the possibility of a disruptive incident. It also enables, if such incident occurs, an appropriate response. Hence, it can dramatically reduce the damage of such an incident. The idea is that the impact that different disasters may have on a business become clear once this analysis is complete (Botha and Von Solms 2004).

Discussions about analysis and appraisal procedures for preparing port logistics BCPs were led by SATREPS Chile work group 4b (hereinafter referred as WG4b), and port people from Iquique actively participated. A schematic view of the BCP preparation procedures is shown in Figure 3. The procedure includes three major steps for analyzing and appraising potential risks of the port logistics functions, i.e.: the Business impact analysis (BIA), the Risk assessment (RA) and the Business continuity strategy development.

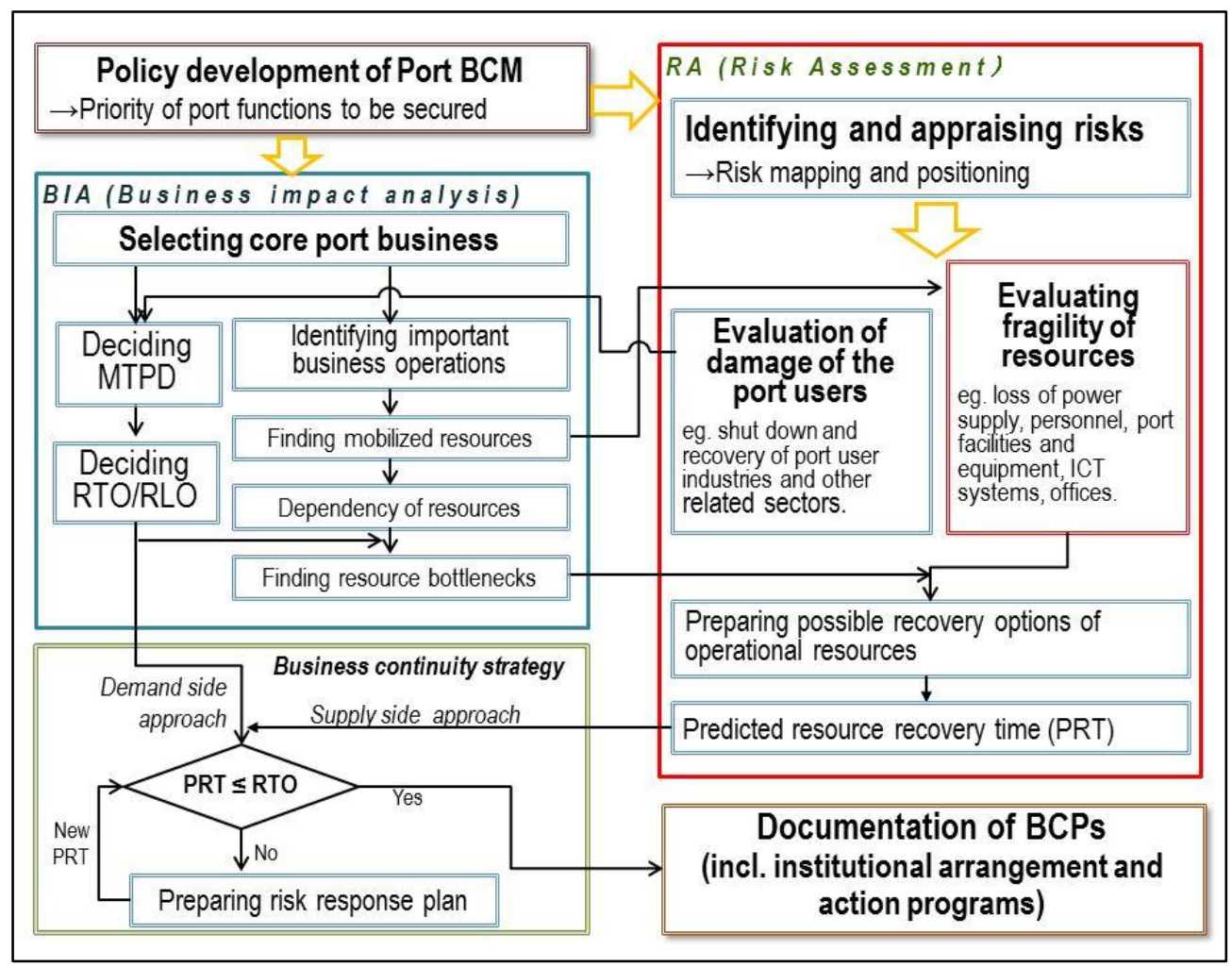

Figure 3 Suggested procedures for preparing port BCPs

The BIA process enables port managers to understand the magnitude of operational and financial impacts associated with a disaster. It also provides them with information about the business interest of the port clients in order to judge how long they can wait for the recovery of port logistics functions and what are the minimum port services needed to meet the requirements for their business activities at the 
port. These requirements by the clients are expressed as the concept of the maximum tolerable period of downtime (MTPD) which is essential for estimating recovery time objective (RTO) and recovery level objective (RLO) of the port logistics function. The BIA is expected to provide accurate and objective evaluation of MTPD, RTO and RLO; thus, should be based on scientific and systematic approaches.

Another target of BIA is to identify critical resources needed for the sound port operation. The meaning of a disaster is, in short, a loss of some resources needed for livelihood and economic activities. Here resources include human resources, assets and opportunities of receiving social services. From this point of view, the BIA process starts from selecting the most important port businesses, namely "port core businesses”, and identifying important port operations needed for conducting such businesses. These resources are often under mutual interdependent relationships. Multiple resources sometimes rely on the supply of only a few other resources, which are in general called "bottleneck resources". It is later discussed that the bottleneck resources decide the necessary time for recovering port functions. As such, the bottleneck resources are of great importance for the port to meet the clients' requirements.

The mission of RA in Figure 3 includes identifying the most critical natural risk to the port, evaluating magnitude of the negative impact on the resources due to the natural disaster, and estimating the needed recovery efforts of the damaged resources.

The most important parameters obtained from the RA are the predicted recovery times (PRTs) and the predicted recovery levels (PRLs), which have to be compared with RTO and RLO in order to prepare the business continuity strategy. PRTs are sometimes much longer than RTO because of the time estimated for the completion of the recovery works for critical resources. Therefore, the port managers are requested to curtail the PRTs in order to meet the RTO and RLO, which should be accomplished through the measures defined in the business continuity strategy.

\subsection{Port system: Difference between business and public service entities}

Chapter 4 of ISO22301 places particular emphasis on the leadership, which is vital for efficient and effective implementation of the BCM. This is of particular relevance for the ports, given its administrative and business characteristics, as follows.

One of the particularities of undertaking BIA in a port is likely to be its governance structure, which normally includes multiple independent entities, from public regulatory organizations such as port authority, harbor master, CIQ offices and local municipality, to port businesses such as shipping companies, stevedoring companies, shipping agencies and port service providers. These entities normally evaluate and respond to risks independently, based on their respective information, interests and norms; therefore implementing BCM in line with a single BCP sometimes looks like substantially impossible.

In particular, public and private entities tend to think in an opposite manner on a disaster scene. Typical examples might be those of the harbor master and the shipping companies, under the aftermath of a disaster. The companies may request an earlier resume of port calls while the harbor master may be reluctant, giving a higher priority to safe navigation. Another example is that an emergency rehabilitation procedure of damaged quays may benefit some stevedoring companies and shipping companies. This fact might discourage the other companies to actively participate under a single BCM scheme.

So, a port community by nature may find it difficult to jointly prepare and implement a single BCM. However, through discussions under SATREPS Chile project the authors learnt and consider it possible to: i) share risk scenario for developing the common target of the port BCM among the port community, ii) identify and agree on the mission of respective port entities to be included in their own BCPs or emergency responding programs, iii) improve capacity to undertake respective BCM under cooperation and mutual assistance among the community, and iv) integrate risk management efforts of the community members for reviewing the risks scenario and awareness. This may pave the way of preparing an 
overarching plan for improving port logistics continuity, and mutual assistance arrangements in order to cope with requests from the port clients.

\subsection{Significance of BIA implementation in Chilean ports}

As stated, BIA is highly important for providing precise information about the port logistics business requirements; this idea is supported by Lin et al. (2012) who indicated that a business contingency plan is highly dependent on industrial characteristics such as type, structure, company location, business operation style, internal business processes, and supply chain. However, it is likely that companies within a specific industry will share some common elements that shape the specific context for each company. In this sense, it will be helpful to identify these elements from the Chilean port system, which will be part of the context of each port.

Currently the Chilean port system includes 56 ports: 10 state ports for public use including 7 ports operating under concession contracts, 14 private ports for public use and 32 ports for private use (MTT, n.d.). Until 1997 the national port system in Chile was controlled and managed by EMPORCHI (Chilean Port Company), when the Chilean government enacted the law $\mathrm{N}^{\circ} 19542$ that reformed the state owned port sector by following three courses of action of: i) creating 10 independent port companies which are assigned to undertake main roles to manage, operate, develop, and maintain state owned ports, ii) modernizing labor issues, and iii) allowing participation of private companies in the development of state ports through concessions for the exclusive operation of some berths of each port, and keeping the administration of the rest of the berths in the state company. This change in the port policy led to the state port companies to become legal entities with autonomy and decentralized power. The port companies are requested to focus on managing infrastructure by themselves or allowing private sector participation through concession contracts into the port operation. Furthermore, this law gives the Ministry of Transport and Telecommunications (herein MTT) the power to modify the port areas, as well as a broader strategic mandate, that includes functions as to propose strategic plans for the state ports development (MTT 2014).

Thus, along with the board of directors and the concessionaire (where there is any), the state ports relate with 3 key members of the State: i.e. i) The Enterprises System of the Ministry of Economy, to which the port companies belong. The Ministry is responsible for supervision and control of their management. The Ministry nominates and removes members of the board of directors of each port company; ii) the MTT, which provides the national policies and goals for each port; and iii) the Directorate of Port Works of the Ministry of Public Works, which is responsible for port infrastructure technical issues. Figure 4 shows such relations.

The new model for the national port system allowed an increase in both the cargo transferred and revenues, and a reduction in operating costs (SEP 2006), according to Carrillo and Santander (2005) this increase in the transfer rate in part is explained because of the investment in high-tech equipment for cargo transfer and in infrastructure to receive larger ships. The state ports are located along the 4,000 km of the Chilean coast ${ }^{4}$, so they must address the specific requirements of the regional economy where they are located: e.g., in the north, mining and fishing industries, in the center agriculture industry and in the south aquaculture and forestry industries. Hence, BIA is important to understand who the related stakeholders are and what their specific needs are, in order to prepare an appropriate business continuity strategy for each port.

\footnotetext{
${ }^{4}$ Considered linearly
} 


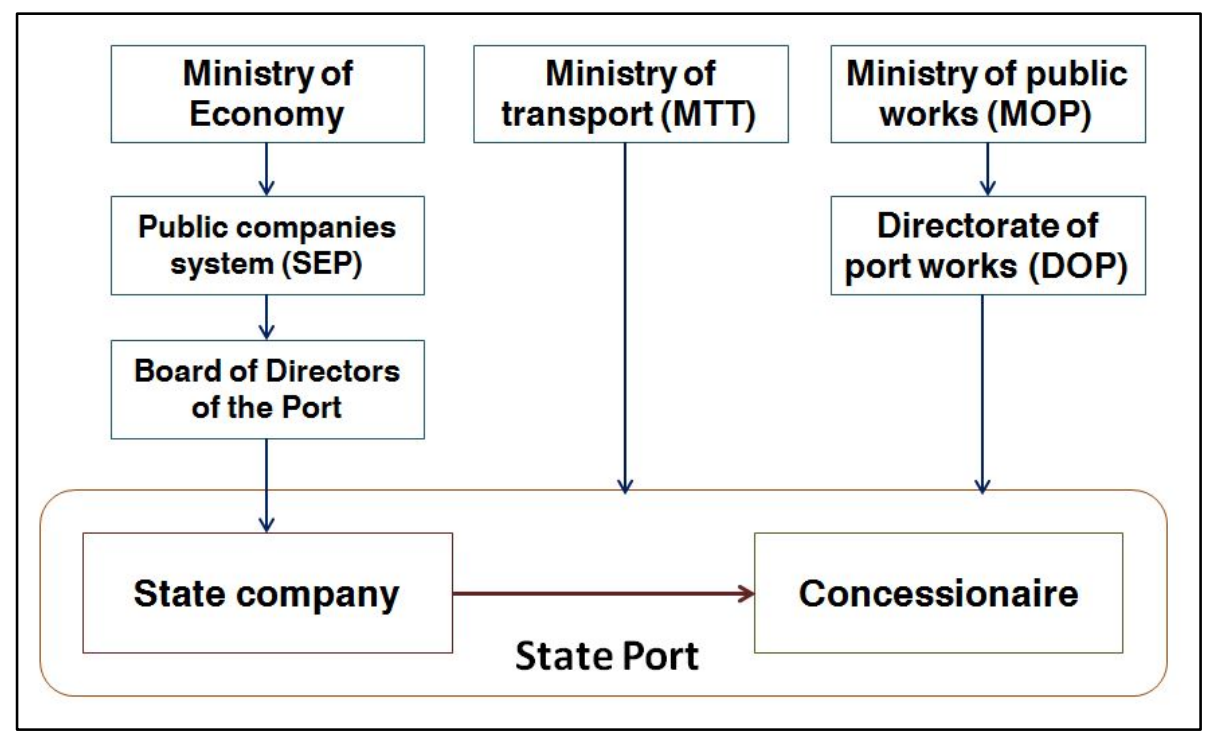

Figure 4 Relations within the national port system (state players)

\subsection{Lesson learnt from past disasters.}

Immediately after the Great East Japan Earthquake in 2011, emergency rehabilitation works were undertaken by the Japanese government in the affected ports. The less damaged wharves were prioritized to attend emergency relief logistics by sea, for which a minimum clearance of water area was secured almost within two weeks. As a result, the first emergency relief ship arrived on March 16, 2011 at the port of Miyako, Iwate prefecture, followed by neighboring ports on March 18, March 19 and March 23. Until August 15, 2011, 871 ships had arrived in major ports of Tohoku for bringing in relief supplies for the disaster area. (MLIT 2012)

However, this did not necessarily mean, that these ports had immediately come back for commercial use. The cargo handling and storage functions of these ports were lost because of the tsunami, which derailed quay gantry cranes, demolished transit shed and warehouses, and damaged cargo handling equipment. Consequently, cargo handling functions of the majority of ports were still unrecoverable after the completion of clearing the waterways and rehabilitation of quay structures. It resulted in delays on resuming of the regular shipping links, in particular, of the container shipping services, for which loading and unloading operations by quay gantry cranes were essential. A good example of this is the port of Sendai-Shiogama, where it took three months to resume coastal container shipping services, 6 months for the container links with Asian neighboring economies and 10 months for intercontinental link with North America.

One of the effects observed was that port calls of international container ships were delayed because of the time-consuming repair works of quay gantry cranes, which restarted operation only on September 2, 2011. Meanwhile, small container vessels for coasting came back on June 1, 2011 for linking Tohoku with ports of Tokyo and Yokohama. However, the reopening of the international trunk container line with North America was on January 22, 2012, more than 10 months after the disaster.

The delay in recovery of port functions seriously affected the restoration of the local economy. One example is the case of the port of Ishinomaki, where a paper-manufacturing company located at the port area, fully resumed operation one year after the disaster. Hence, it suffered a decrease of market share due that long absence. Another example is the case of the grain terminal at Ishinomaki that suspended its operation and had to be temporarily merged with Hachinohe Port.. 
As such, the lesson learnt from the Great East Japan Earthquake highlighted that the critical operational resources are essential for the early recovery of the port logistic operations. Therefore, they are of great importance in the BCM context.

\section{FRAMEWORK AND PROCEDURE FOR BIA IN PORTS}

As stated in chapter 3.1, the main goals of BIA is to obtain the MTPD, RTO and RLO, along with the bottleneck operational resources. The procedure conducted by the SATREPS working group 4b is described below.

\subsection{Procedure for implementing BIA}

The whole view and outlines of the BIA implementation procedure is recommended by the authors as a flow chart diagram shown in Figure 5. BIA starts by screening current port businesses to select its "core business", for which the needed operational resources with mutual dependency of the resources and their bottlenecks, and the requested recovery time period and service level are identified. The procedures are divided into eight steps, for which work sheets are prepared for guiding the BIA analyst.

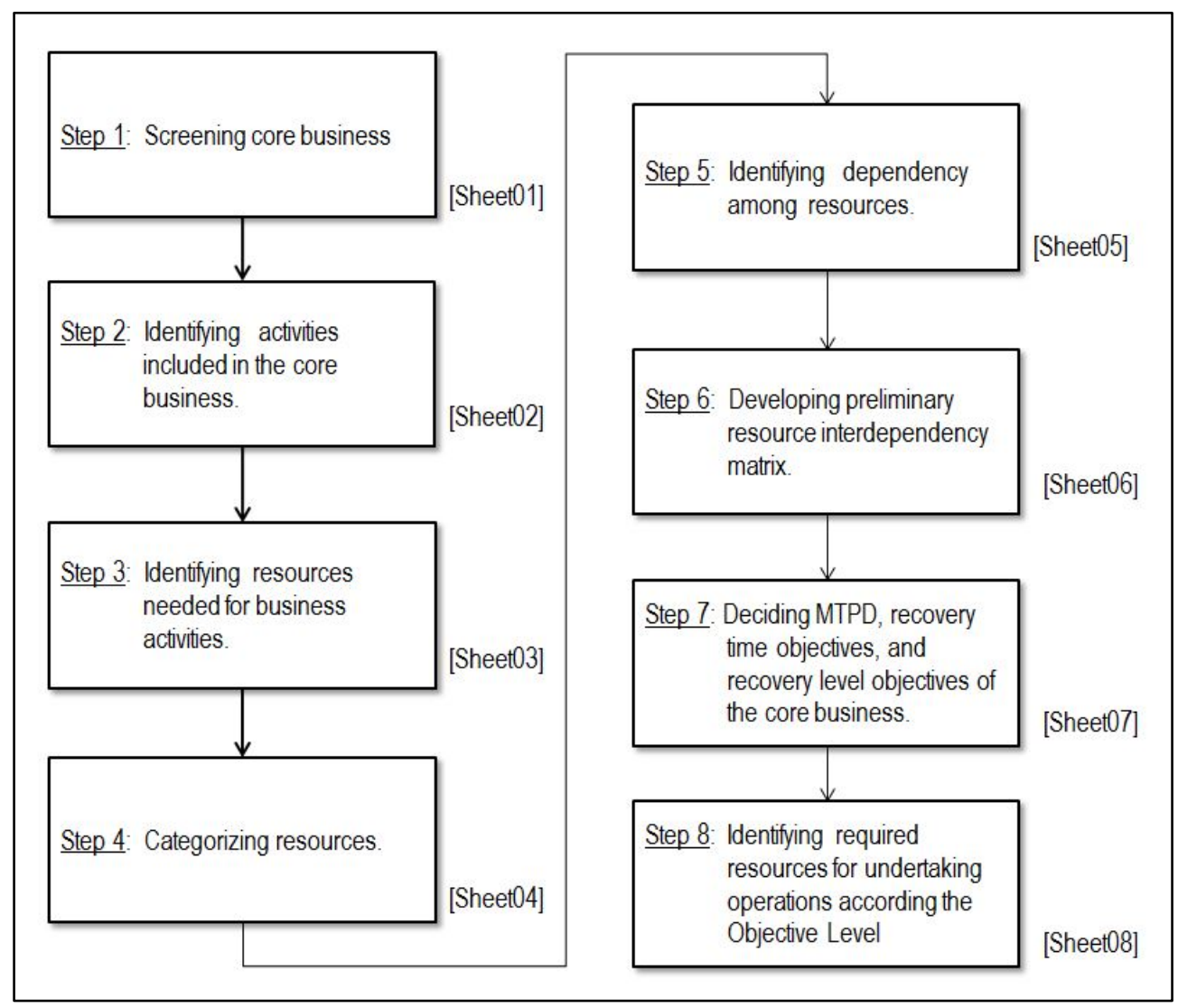

Figure 5 Flow chart of BIA procedures and steps

As stated before, among the output of BIA is the MTPD, which is essential to understand the port clients' limitation of the tolerance as well as the RLO and the RTO. So, the MTPD indicates the maximum period the port logistics can be suspended. Once failure to meet this requirement occurs, it may 
affect the market credibility and competitiveness of the port's core business, resulting in losing market position. RTO and RLO are determined by considering the time rugs (or lead time) and minimum requirements of the port logistic functions under the aftermath of the disaster. Another target of the BIA is, as stated in the former chapter, identifying interdependency and bottlenecks of operation resources.

A schematic view of the MTPD, RTO and RLO is shown in Figure 6, which suggests that normally the period of RTO is less than the MTPD because of the time rug needed for mobilizing BCP responding actions and for preparing resume of the service.

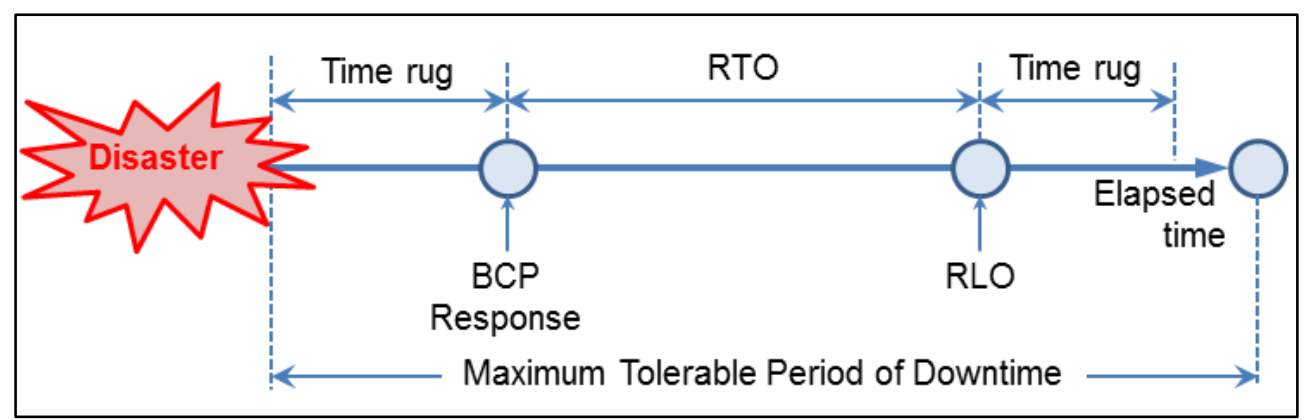

Figure 6 Schematic view of MTPD, RLO and RTO

\subsection{Goals and methodology of BIA}

After finding the core business of the port, there are two tracks of processes to be undertaken as shown in Figure 3, decision of MTPD and Identifying important business operations. Among them, the evaluation of MTPD is prone to be evaded because of the lack of clear approach. The authors consider the evaluation of the MTPD through: i) consideration of health and humanitarian situation of local residents, ii) discussion on possible damage and loss suffered by the port clients including consignee/consignor and shipping company, iii) projection of port cargo throughput after the disaster, and iv) remaining volume of the stocks of fuel, industrial material and other local inventory.

The possible impact on the logistics business caused by port shutdown should be evaluated under the broad discussion with the participation of the site managers and practitioners as well as port management. The procedures, discussions and analysis should be properly documented and reported for future review and improvement of BCP. Many BCP textbooks offer templates of worksheets for preparing BCP, based on which the authors develop a series of worksheets for undertaking BIA and RA for BCPs in Chilean ports.

One of the advantages of the worksheet system is that increases transparency in the procedures. The authors consider that it is much easier for the practitioner, and for third parties, to trace and understand the BIA and RA analysis with this "step by step" approach for obtaining BCP parameters, based on wellprepared worksheets. As such, the worksheet system is expected to facilitate broader participation of port community members and wider echelons ranging from top management to site staff in the BCM preparation, implementation and monitoring. Another means to facilitate broad participation may include working group discussions for aggregating in-site expertise, knowledge and information for the BCP preparation (Komatsu et al. 2013, Ono et al. 2014)

\subsection{Risk response plan}

Following the BIA and RA procedures should be developed the business continuity strategy, to achieve the objectives defined for resuming port logistics function. The strategy could include 
countermeasures such as strengthening of structures of the port facilities, improving stockpiles of construction materials for emergency rehabilitation, shearing inventory of cargo handling equipment and parts, accelerating procurement procedures, and improving redundancy of external supplies (Table 1).

Table 1 Possible measures for developing port continuity strategy

\begin{tabular}{|c|c|c|c|c|c|c|c|}
\hline & & & $\begin{array}{l}\text { Strengthening } \\
\text { structure }\end{array}$ & Stockpile & $\begin{array}{l}\text { Shearing } \\
\text { inventry } \\
\text { information }\end{array}$ & $\begin{array}{l}\text { Acceralating } \\
\text { procurement } \\
\text { procedures }\end{array}$ & Redundancy \\
\hline \multirow{2}{*}{$\begin{array}{l}\text { Infra - } \\
\text { structure }\end{array}$} & \multicolumn{2}{|c|}{ Port facilities } & $\mathrm{O}$ & & & & $\mathrm{O}$ \\
\hline & \multicolumn{2}{|l|}{ Road } & 0 & & & & 0 \\
\hline \multirow{4}{*}{$\begin{array}{l}\text { Human } \\
\text { resiurce }\end{array}$} & \multicolumn{2}{|l|}{ Civil works } & & & 0 & 0 & \\
\hline & \multirow{2}{*}{$\begin{array}{l}\text { Port } \\
\text { operation }\end{array}$} & Cargo handling & & & 0 & $\triangle$ & \\
\hline & & Port services ${ }^{* 1}$ & & & 0 & $\triangle$ & \\
\hline & \multicolumn{2}{|l|}{ Ship crue } & & & 0 & $\triangle$ & \\
\hline \multirow{5}{*}{$\begin{array}{l}\text { Materials / } \\
\text { equipment }\end{array}$} & \multirow{2}{*}{$\begin{array}{l}\text { Reconstru } \\
\text { ction }\end{array}$} & $\begin{array}{l}\text { Construction } \\
\text { material }\end{array}$ & & O & $\mathrm{O}$ & O & \\
\hline & & Equipment & & & 0 & 0 & \\
\hline & \multirow{2}{*}{ Operation } & $\begin{array}{l}\text { Cargo handling } \\
\text { equipment }{ }^{* 2}\end{array}$ & & & O & O & \\
\hline & & $\begin{array}{l}\text { Port service } \\
\text { equipment }\end{array}$ & & & O & O & \\
\hline & \multicolumn{2}{|l|}{ Ship } & 0 & & 0 & $\triangle$ & \\
\hline \multirow{4}{*}{ Supplies } & \multicolumn{2}{|l|}{ Electricity } & O & & & & 0 \\
\hline & \multicolumn{2}{|c|}{ Water supply } & $\mathrm{O}$ & & & & 0 \\
\hline & \multicolumn{2}{|l|}{ City gas } & 0 & & & & $\mathrm{O}$ \\
\hline & \multicolumn{2}{|c|}{ Waste disposal } & O & & & & O \\
\hline
\end{tabular}

\section{TECHNIQUES FOR BIA PROCEDURES}

This section introduces some particular techniques to be used when port community tackles BCP preparation. These techniques were used in Iquique Port and may be used to follow a systematic procedure for avoiding unnecessary dependence on personal capacity and judgment, and to achieve transparency and traceability for later review and update.

\subsection{Work flow analysis}

In view of the above discussions, the authors recommend the use of business flow analysis based on the IDEF0 method $^{5}$ as an indicative methodology for identifying the detail steps of business operations and resources needed. It is necessary to note that, as shown in Figure 5, the first step of the BIA is to identify the core business of the port; however this will be explained in the following point.

${ }^{5}$ IDEF0 (Integrated DEFinition method 0) may be defined as a business process modeling tools, developed by a research group in US air base in Oklahoma. 
The business flow analysis is a technique that uses diagrams to breakdown the business process structure. The IDEF0 is a function modeling method designed for identifying decisions, actions, and activities included in an organizational function or social/information system. Komatsu et al. (2013) introduced "job cards" for developing a business flow diagram of a water treatment plant in Osaka, Japan. A template of a job card modified by the authors for port BCP preparation, and a business flow diagram, are illustrated in Figure 7 and Figure 8, respectively.

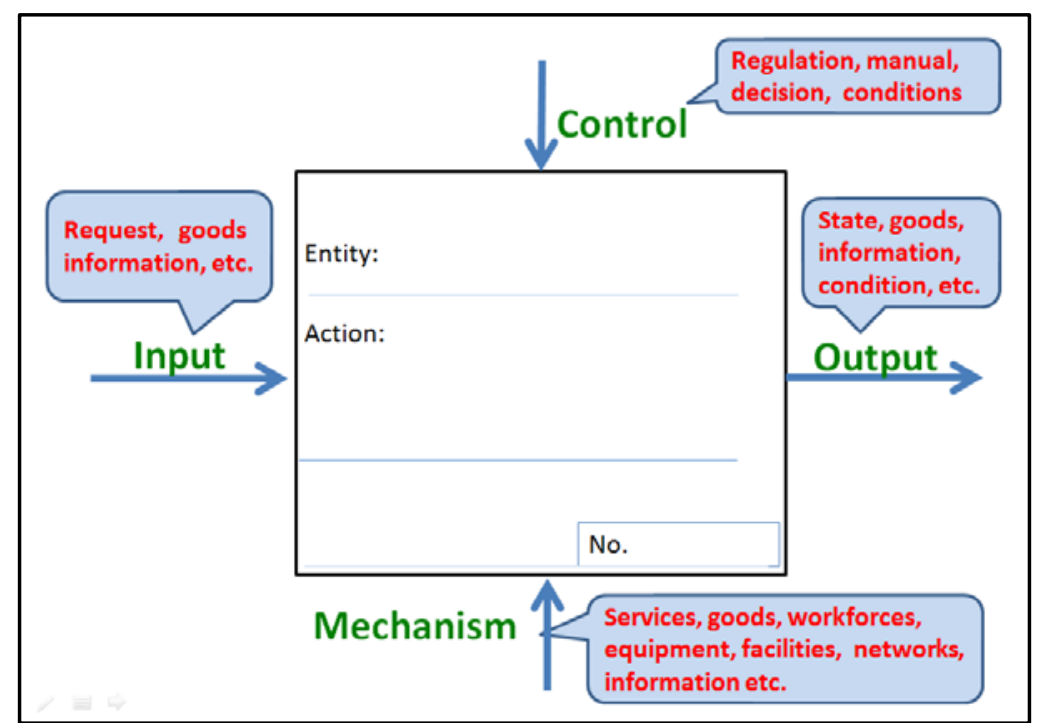

Figure 7 Modified job card for Port BCP preparation

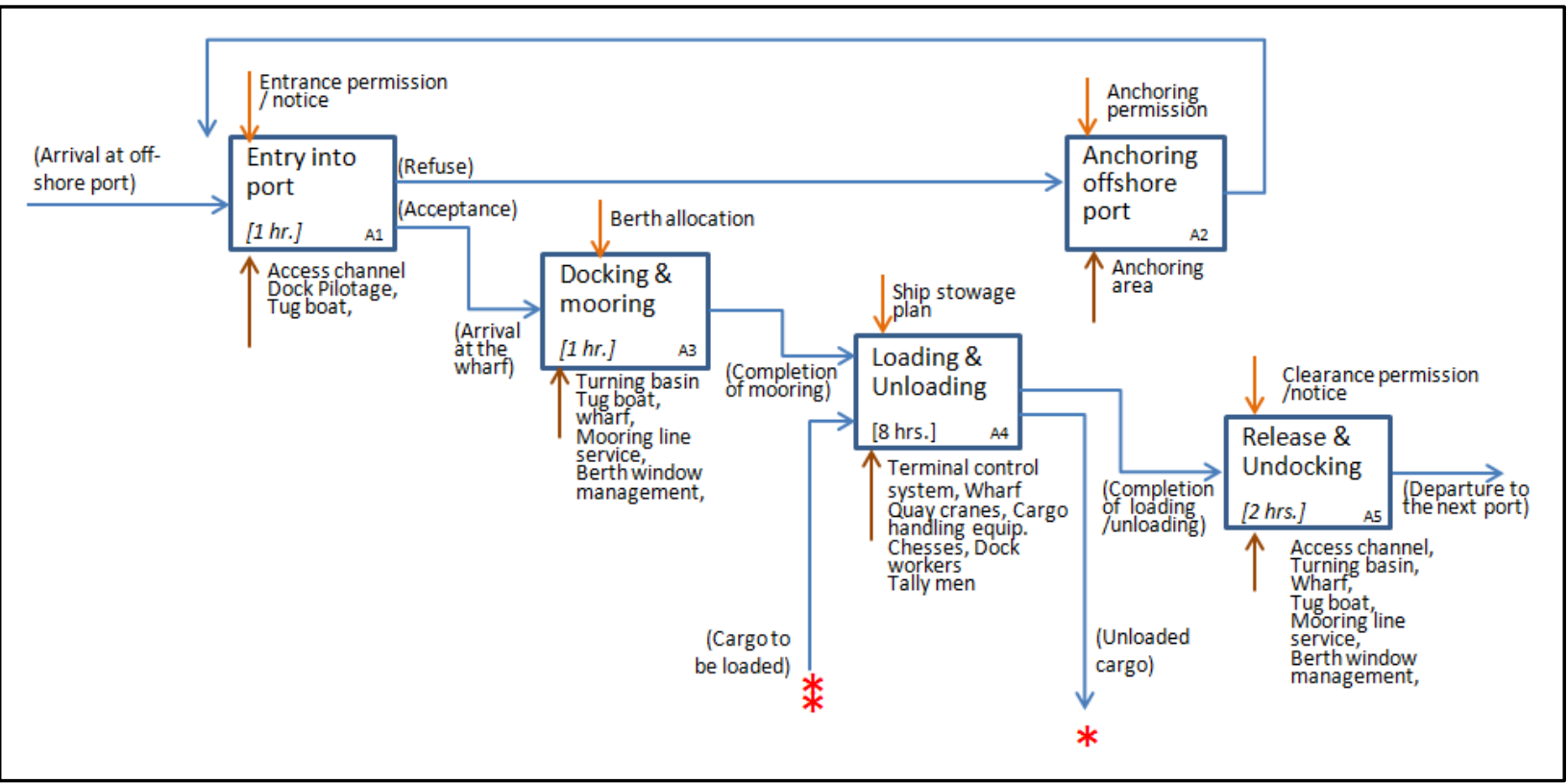

Figure 8 An example of business flow diagram for Port BCP preparation

A business flow diagram is described as an event chain system, where the job card identifies: i) necessary operational steps, and ii) essential resources, for properly implementing the port core business. 
For this analysis there are two inputs to take under special consideration in each job card: i.e. "mechanism" from below and "control" from the top, as shown in Figure 7. The mechanism includes resources directly needed for processing the step, and control represents necessary information for processing such as permission, notification, order, guidelines, program, and any other regulations and conditions of concern.

As a result of the business modeling, a complete description of the core business, including the direct resources needed, can be obtained. The next task is the identification of dependencies among resources. using the worksheet system.

\subsection{Worksheet system}

The worksheet system is likely an effective means to address, evaluate and identify port core business, the maximum tolerance of the port clients, and dependency among port operation resources.

The worksheet for screening major port business and identifying port core business is a starting point of BIA. The worksheet shown in Table 2 is provided by the authors based on commonly-used BCP worksheets (Kon 2009). The worksheet assists in selecting the core businesses to be included in the BCM by rating the possible negative impacts of the port shutdown in association with certain criteria, such as possible future port development, securing major shipping links and financial soundness of the port management. Once the core businesses are selected, the business flow can be analyzed as shown in the previous section.

Table 2 Proposed worksheet for screening port core business

\begin{tabular}{|c|c|c|c|c|}
\hline \multicolumn{2}{|c|}{ Selection policy } & \multicolumn{3}{|c|}{ Rating } \\
\hline Criteria & $\begin{array}{l}\text { Specific impacts/risks of lossing } \\
\text { business. }\end{array}$ & $\begin{array}{c}\text { Core business } \\
\text { candidate } 1\end{array}$ & $\begin{array}{c}\text { Core business } \\
\text { candidate } 2\end{array}$ & $\begin{array}{c}\text { Core business } \\
\text { candidate } 3\end{array}$ \\
\hline \multicolumn{5}{|c|}{$\begin{array}{l}\text { Taget/objectives of port management } \\
\text { 1. Possible future development }\end{array}$} \\
\hline \multicolumn{5}{|c|}{ 2. Maintaining international shipping links } \\
\hline \multicolumn{5}{|c|}{ Total score } \\
\hline \multicolumn{2}{|c|}{ Inclusion or exclusion in $\mathrm{BCP}$} & $\begin{array}{l}\text { Include } \\
\text { lexclude }\end{array}$ & $\begin{array}{l}\text { Include } \\
\text { lexclude }\end{array}$ & $\begin{array}{l}\text { Include } \\
\text { lexclude }\end{array}$ \\
\hline
\end{tabular}

(Impact rating: $A=$ high [2], B=Medium [1], C=low [0])

The worksheet developed by the authors for evaluating MTPD for the port of Iquique is shown in Figure 9. The impact of the shutdown of port core business is evaluated in association with the client's tolerance. The criterion should be set forth under discussions among site managers and commitment of the top management. Notice that RTO is calculated based on MTPD and time rug parameters 


\begin{tabular}{|c|c|c|c|c|c|c|c|c|c|c|c|c|}
\hline \multicolumn{5}{|l|}{ [Targets] } & & \multicolumn{7}{|c|}{ [Impact Rating] } \\
\hline Core Business & \multicolumn{4}{|c|}{ Container terminal operation } & \multicolumn{3}{|c|}{ Impact } & \multicolumn{2}{|c|}{ Low [L] } & \multicolumn{2}{|c|}{ Medium [M] } & High [H] \\
\hline \multirow{2}{*}{$\begin{array}{l}\text { Major stake } \\
\text { holder }\end{array}$} & \multirow{2}{*}{\multicolumn{4}{|c|}{$\begin{array}{l}\text { Dirección de Obras Portuarias } \\
\text { Iquique Terminal International (ITI) } \\
\text { Empresa Portuaria Iquique(EPI) }\end{array}$}} & & \multirow{2}{*}{\multicolumn{2}{|c|}{\begin{tabular}{|l} 
Port \\
creditability \\
undermined \\
Shippers'migrat \\
ion
\end{tabular}}} & \multirow{6}{*}{\multicolumn{2}{|c|}{$\begin{array}{c}\text { No impact / } \\
\text { very small } \\
\text { expected }\end{array}$}} & \multicolumn{2}{|c|}{$\begin{array}{l}\text { Temporal, } \\
\text { Recoverable }\end{array}$} & $\begin{array}{l}\text { Full-scale. } \\
\text { Unrecoverable }\end{array}$ \\
\hline & & & & & & & & & & \multicolumn{2}{|c|}{$\begin{array}{c}\text { Partial, } \\
\text { Recoverable }\end{array}$} & $\begin{array}{l}\text { Full-scale. } \\
\text { Unrecoverable }\end{array}$ \\
\hline \multicolumn{5}{|c|}{ [Time range parameters] } & & \multirow{2}{*}{\multicolumn{2}{|c|}{$\begin{array}{l}\text { Withdrawal of } \\
\text { shipping line }\end{array}$}} & & & \multirow{2}{*}{\multicolumn{2}{|c|}{$\begin{array}{l}\text { Temporal, } \\
\text { Recoverable }\end{array}$}} & \multirow{2}{*}{$\begin{array}{l}\text { Long-term, } \\
\text { Dead-end }\end{array}$} \\
\hline $\begin{array}{l}\text { Additional time } \\
\text { (days) }\end{array}$ & $\begin{array}{r}\text { Mobilization } \\
\text { of BCP (day) }\end{array}$ & \multicolumn{2}{|c|}{$\begin{array}{l}\text { Resource } \\
\text { mobilization }\end{array}$} & & & & & & & & & \\
\hline i) ERL operation & 0,5 & \multicolumn{2}{|c|}{0,5} & & & \multirow{2}{*}{\multicolumn{2}{|c|}{$\begin{array}{l}\text { Shutdown or } \\
\text { relocation of } \\
\text { local industries }\end{array}$}} & & & \multirow{2}{*}{\multicolumn{2}{|c|}{$\begin{array}{l}\text { Limited } \\
\text { companies, } \\
\text { Recoverable }\end{array}$}} & \multirow{2}{*}{$\begin{array}{c}\text { Major } \\
\text { establishment. }\end{array}$} \\
\hline $\begin{array}{l}\text { ii) Commercial } \\
\text { port operation }\end{array}$ & 0,5 & 0 , &, 5 & & & & & & & & & \\
\hline \multicolumn{2}{|c|}{ Impact of port shutdown } & 3 days & 1 week & 2 week & \begin{tabular}{c|c}
1 \\
month
\end{tabular} & \begin{tabular}{c|}
3 \\
month
\end{tabular} & \begin{tabular}{c|c}
6 \\
month
\end{tabular} & 1 year & \begin{tabular}{|l|} 
MTPD \\
(day)
\end{tabular} & $\begin{array}{l}\text { RTO } \\
\text { (day) }\end{array}$ & & RLO \\
\hline \multicolumn{2}{|c|}{ Creditibility as ERL port } & L & M & H & H & H & H & H & 7 & 6 & \multicolumn{2}{|c|}{$\begin{array}{c}\text { Shallow draft ship } \\
\text { accessibility }\end{array}$} \\
\hline \multicolumn{2}{|c|}{$\begin{array}{l}\text { Shippers to migrate neighbor } \\
\text { ports }\end{array}$} & L & L & L & M & H & H & H & 30 & 29 & \multicolumn{2}{|c|}{$\begin{array}{l}\text { Limited cargo handling } \\
\text { capacity }\end{array}$} \\
\hline \multicolumn{2}{|c|}{ Withdrawal of shipping line } & L & L & L & L & M & M & H & 180 & 179 & \multicolumn{2}{|c|}{$\begin{array}{l}\text { Full ship size } \\
\text { accommodation }\end{array}$} \\
\hline \multicolumn{2}{|c|}{$\begin{array}{l}\text { Shutdown or relocation of } \\
\text { local industries }\end{array}$} & L & L & L & L & M & H & H & 90 & 89 & \multicolumn{2}{|c|}{$\begin{array}{c}\text { Regular shipment } \\
\text { services }\end{array}$} \\
\hline \multicolumn{13}{|c|}{ Nota: ERL = Logística de Emergencia y Apoyo } \\
\hline Goa & & \begin{tabular}{|l|l|} 
RTO & \\
\end{tabular} & RLO d & de la Activ & vidad & & & & & & & \\
\hline Support ERL acti & ties & 6 & $\begin{array}{r}\text { Shallc } \\
\text { ac }\end{array}$ & ow draft & $\begin{array}{l}\text { ship } \\
\text { ty }\end{array}$ & & & & & & & \\
\hline Avoid shippers mi & ration & 29 & Limited & $\begin{array}{l}\text { cargo ha } \\
\text { capacity }\end{array}$ & ndling & & & & & & & \\
\hline $\begin{array}{l}\text { Support recovery } \\
\text { industries }\end{array}$ & f local & $\begin{array}{c}89 \\
-10 \\
\end{array}$ & Regul & $\begin{array}{l}\text { lar shipn } \\
\text { services }\end{array}$ & nent & & & & & & & \\
\hline
\end{tabular}

Figure 9 Suggested worksheet for deciding MTPD, RTO and RLO

Once the resources have been identified through work flow analysis, the worksheet system is used for the follow up. The work flow diagram provides information about the resources needed for implementing each step of the port's core business. The "mechanisms" indicates direct resources needed, and the "controls" indicates the resources needed to provide such controls. Hence, through the worksheet system all operational resources are identified and categorized through "step by step basis", as displayed in Table 3 and Table 4.

\subsection{Resource dependency matrix}

Often there are interdependent relationships among the operational resources that, as a consequence, create resource bottlenecks, as illustrated in Figure 10. An example is the interdependence between wharf, mobile crane and tug boat: the wharf cannot undertake loading and unloading operation without assistance of those facilities, which fully rely on fuel oil supply; therefore, function of wharf eventually depends on the fuel supply. So, fuel oil is found to be a critical resource through tracking process of resource dependency. These tracking processes are described as "resource dependency matrix", which sequentially follows dependency of resources and find possible bottleneck resources for the port core business as demonstrated in Figure 11. 
Table 3 Suggested worksheet for identifying operational resources

\begin{tabular}{|c|c|c|c|c|c|}
\hline \multirow[b]{2}{*}{$\begin{array}{l}\text { ID } \\
\text { Nos }\end{array}$} & \multirow[b]{2}{*}{ Business activities } & \multirow[b]{2}{*}{ Control } & \multirow{2}{*}{$\begin{array}{l}\text { Control } \\
\text { administrations/ } \\
\text { Managements }\end{array}$} & \multicolumn{2}{|c|}{ Resources } \\
\hline & & & & Direct input & Needed for control \\
\hline A1 & Entry into port & Entrance permission/notice & $\begin{array}{l}\text { Harbour master. } \\
\text { Port authority }\end{array}$ & Access channel, Dock Pilotage, Tug boat & $\begin{array}{l}\text { Harbour masrer staff, Hqs. building, and OA equipment } \\
\text { Port authority staff, office and OA equipment }\end{array}$ \\
\hline A2 & Anchoring off the shore port & Anchoring order & Harbour master. & Anchoring area & Harbour masrer staff, Hqs. building, and OA equipment \\
\hline A3 & Docking \& mooring & Berth allocation & Port authority & Turning basin, Tug boat, Wharf, Mooring line service, & Port authority staff, office and $\mathrm{OA}$ equipment \\
\hline A5 & Release \& Undocking & Clearance premission/notice: & $\begin{array}{l}\text { Terminal operation } \\
\text { company }\end{array}$ & $\begin{array}{l}\text { Access channel, Turning basin, Wharf, Tug boat, Mooring } \\
\text { line service, Berth window management, }\end{array}$ & $\begin{array}{l}\text { g Staff, office, and OA equipment of the terminal operation } \\
\text { company. }\end{array}$ \\
\hline
\end{tabular}

Table 4 Suggested worksheet for categorizing operational resources

\begin{tabular}{|c|c|c|c|c|c|c|}
\hline & \multirow[b]{2}{*}{ Business activities } & \multirow[b]{2}{*}{ Control } & \multicolumn{4}{|c|}{ Resources } \\
\hline & & & Outside services & workforces & Facilities \& equipment & ICT \& networks \\
\hline A1 & Entry into port & $\begin{array}{l}\text { Entrance } \\
\text { permission/notice }\end{array}$ & Power supply & $\begin{array}{l}\text { Harbour masrer official, port } \\
\text { authority staff, dock Pilotage }\end{array}$ & Access channel, Tug boat & $\begin{array}{l}\text { OA equipment of harbour masrer } \\
\text { and port authority }\end{array}$ \\
\hline A2 & Anchoring off the shore port & Anchoring order & & Harbour masrer official & Anchoring area & $\mathrm{OA}$ equipment of harbour masrer \\
\hline A3 & Docking \& mooring & Berth allocation & Power supply & Port authority staff, line men & Berth, turning basin & $\begin{array}{l}\text { Berth window management, } \mathrm{OA} \\
\text { equipment of port authority }\end{array}$ \\
\hline A4 & Loading \& Unloading & Ship stowage plan & Power supply & $\begin{array}{l}\text { Dock workers, tally men, staff } \\
\text { of the terminal operation } \\
\text { company. }\end{array}$ & $\begin{array}{l}\text { Wharf, Quay cranes, cargo handling } \\
\text { equipment, yard trailer/chassis }\end{array}$ & $\begin{array}{l}\text { Terminal control system, OA } \\
\text { equipment of port authority }\end{array}$ \\
\hline A5 & Release \& Undocking & $\begin{array}{l}\text { Clearance } \\
\text { premission/notice: }\end{array}$ & Power supply & $\begin{array}{l}\text { Harbour masrer official, port } \\
\text { authority staff, dock Pilotage, }\end{array}$ & $\begin{array}{l}\text { Access channel, Turning basin, Wharf, } \\
\text { Tug boat }\end{array}$ & Berth window management, \\
\hline
\end{tabular}

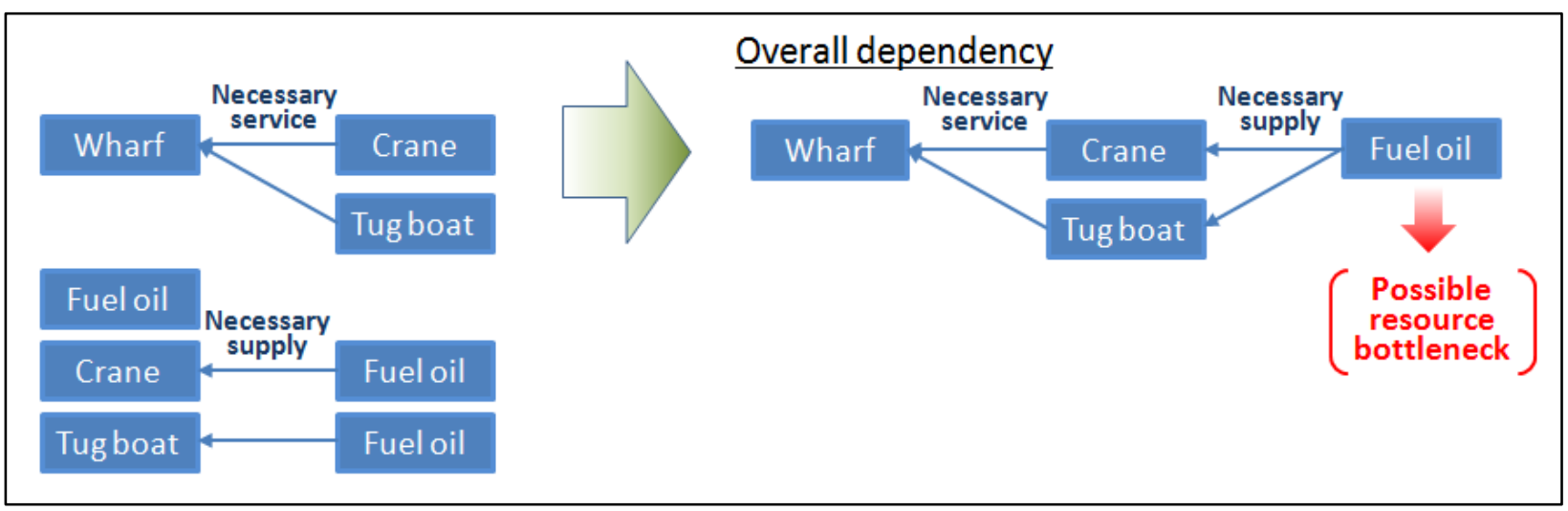

Figure 10 Analyzing critical relationships among resources 


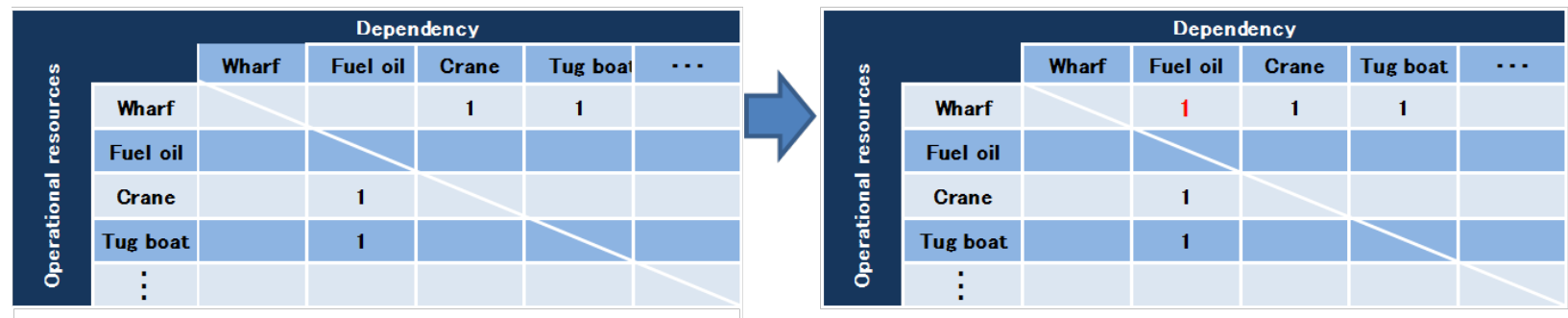

Figure 11 Example of the resource dependency matrix operation

Tracking algorism included in the resource dependency matrix is as the followings: i.e.

The mutual relationship of operational resources is expressed by an $N \times N$ matrix as shown in formula (1) and (2)

$$
\begin{aligned}
& \mathrm{X}_{\mathrm{ij}}=\left\{\begin{array}{l}
1: \mathrm{f} x_{i} \rightarrow x_{j} \\
0: \mathrm{f} x_{i} \rightarrow x_{j}
\end{array}\right. \\
& {\left[\begin{array}{ccc}
X_{11} & \cdots & X_{N 1} \\
\vdots & \ddots & \vdots \\
X_{1 N} & \cdots & X_{N N}
\end{array}\right]} \\
& D_{i j} \cap D_{j k} \rightarrow D_{i k} \quad \mathrm{i}, \mathrm{j}, \mathrm{k}=1-\mathrm{N}
\end{aligned}
$$

Here,

f $x_{i} \rightarrow x_{j}$ : Dependency of resource $\left(x_{i}\right)$ to resource $\left(x_{j}\right)$

$\mathrm{N}$ : the number of operational resources.

$\mathrm{D}_{\mathrm{ij}}:=\mathrm{X}_{\mathrm{ij}}=1$

When the resource $i$ depends on the resource $j$, this relationship can be expressed as $X_{i j}=1$, and when there is no dependency; as $X_{i j}=0$. When the resource $j$ further depends on the resource $k$, then the resource $i$ depends on the resource $k$ as expressed by formula (3).

Based on the formula (1), (2) and (3), dependencies of all resources are checked and tracked accordingly.

By coupling with the predicted recovery time (PRT) and the predicted recovery level (PRL), this resource dependency matrix defines bottleneck resources, without which it is almost impossible to properly implement the port core businesses. The port managers can give to those resources the first priority to secure them for properly meeting the requirements from clients.

In comparison with the recovery time objective (RTO) and the recovery level objective (RLO), as stated in the sections 3.1 and 4.3, the bottleneck resources may give clear indications of necessary actions to be taken in advance to improve business continuity capacity.

\subsection{Evaluation of the port user demand}

In the aftermath of a disaster, some port's clients initiate to resume using the port; however, the port 
might not be available for ship accommodation due damages of facilities, for which restrictions of time, cost and resources are to be managed. In this context MTPD, RTO and RLO are key factors.

On the other hand, there is a possibility of the port clients also being damaged by the disaster; therefore, they cannot resume full business operation immediately. Figure 12 shows the impact of 2010 Chile Earthquake on port cargo volume.

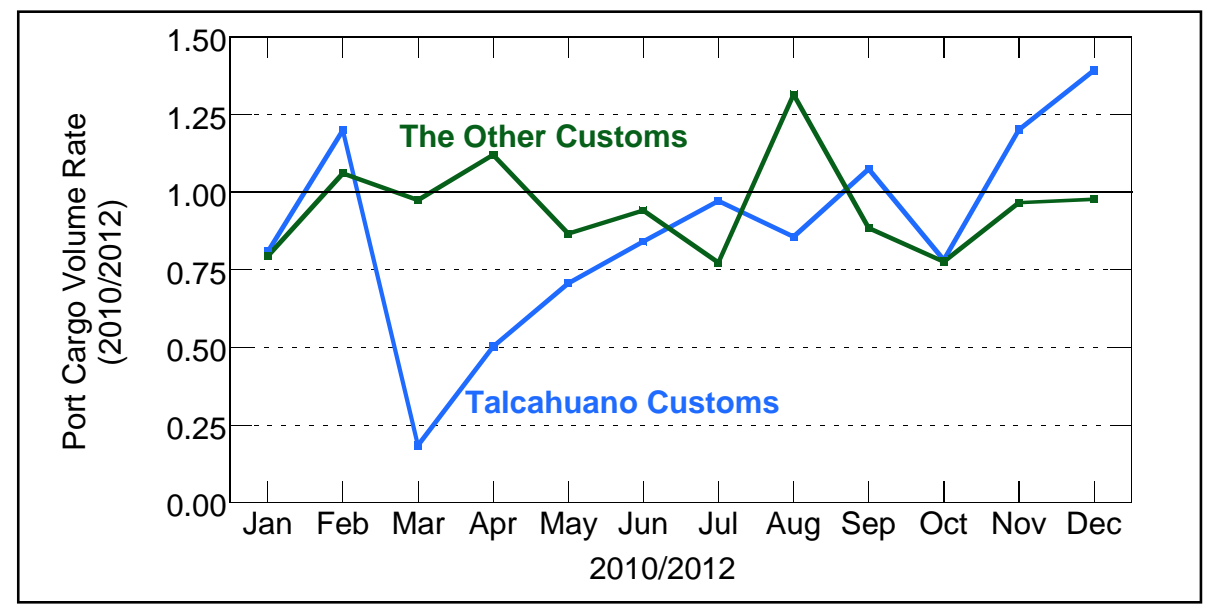

Figure 12 Impact of 2010 Chile earthquake on port cargo volume

On the vertical axis in Figure 12 appears port cargo volume ratio and indicates a proportion of monthly port cargo volumes in 2011 to those in 2010. The port cargo volume ration of Talcahuano port area, which suffered severe damaged by the earthquake and tsunami, dramatically decreased by more than 80 percent in March, and gradually recovered in the following months. This suggests that the port cargo handling demand is notably low; hence it is possible to undertake the recovery works during the two months after the disaster.

As such, it is vital for the port managers to properly estimate the recovery degree of port cargo handling demand. The extent of cargo throughput downturn and recovery speed depends on industrial structure, business conditions, and scale and nature of the hazard. In this view, the authors consider it necessary that the port community, in collaboration with the academia, conducted a survey to identify the possible damage of local industry due to disaster, and its consequences on cargo handling demand at port in the aftermath of the disaster.

Among the currently undertaken studies, a series of demand recovery curves may provide a reference for Chilean ports. Tsunami inundation depth and seismic intensity were considered as the main parameter for the chart of hazard intensities by Japan Meteorological Agency. The chart was developed based on the survey data from Great East Japan Earthquake, and estimates degree of risen demand in the aftermath of disaster (Akakura et al. 2014). 


\section{CASE STUDY OF BIA IMPLEMENTATION IN IQUIQUE PORT}

\subsection{Iquique area and port logistics}

Iquique is the capital of the administrative region of Tarapacá, located at $20.2^{\circ} \mathrm{S}$ and $70.1^{\circ} \mathrm{W}$. With a population of around 186,000 people, it is the largest city in its region. The workforce is composed of nearly 87,000 people, representing $46 \%$ of the regional population (INE 2013).

As capital of the region, the offices of the regional government, which is part of the national government, are located in downtown Iquique. The city is also the capital of Iquique Province. It borders the province of Arica, region of Parinacota, to the North;the province of Tamarugal to the East; the province of Tocopilla,, region of Antofagasta, to the South, and the Pacific Ocean to the West (Figure 13).

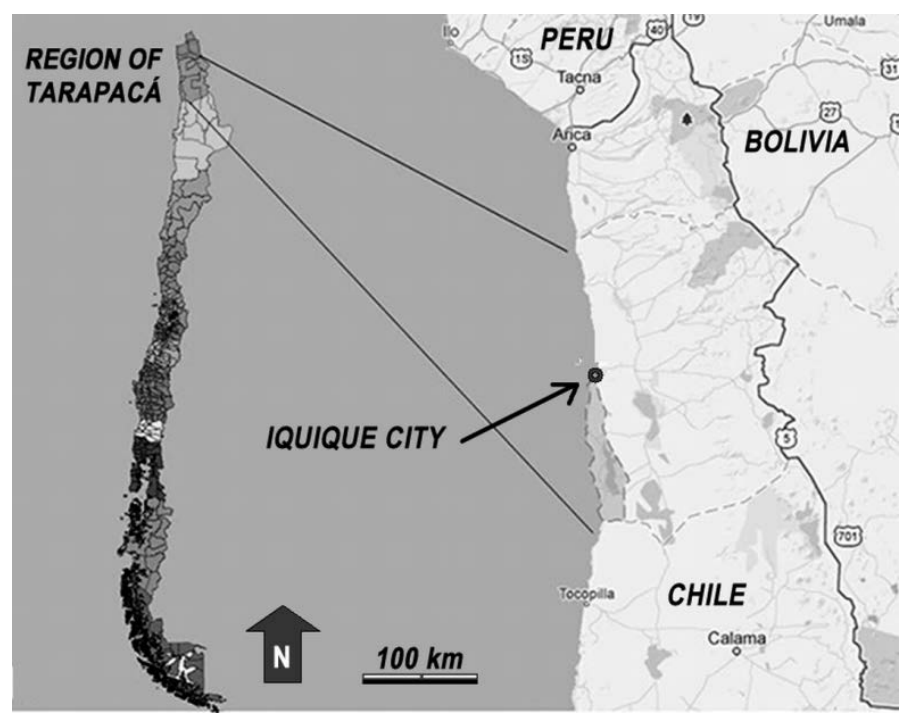

Figure 13 Location of Iquique City in Chile (Region of Tarapacá). Modified from Google maps (2014)

The city is connected to the rest of the country through domestic flights, highways and by merchant ships. There are no commercial passenger ships links along Chilean coast. As Iquique is located in a desert area, the access by road can be very fragile in case of earthquakes. The main land surface access route to Iquique is route 16 that connects with the neighboring commune of Alto Hospicio, and later with route 5-North which goes through almost the entire country. In the southern part of the city there is a coastal route: i.e. route 1, which connects Iquique with Antofagasta city. This situation means the city has a fragile land surface connectivity.

Iquique Port is located at $20^{\circ} 11^{\prime} 59 " \mathrm{~S}$ and $70^{\circ} 09^{\prime} 25^{\prime \prime} \mathrm{W}$, built on a small island connected to the city through a breakwater (Figure 14). Accordingly, as mentioned in chapter 2, the port plays a fundamental role in the local economy. 


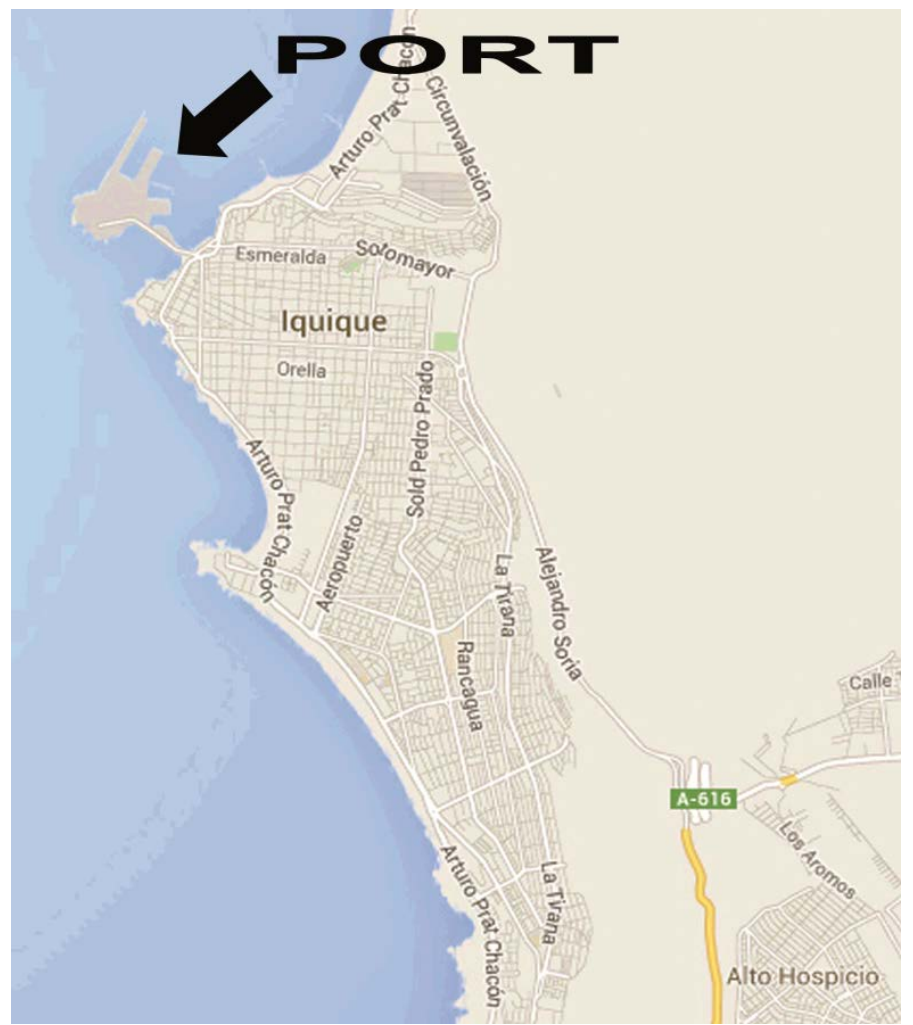

Figure 14 Location of Iquique Port in the city of Iquique. (Google Maps 2014)

The port of Iquique is owned and managed, by "Empresa Portuaria Iquique” (Iquique Port in Spanish, hereinafter referred as EPI), and includes two terminals: Terminal $\mathrm{N}^{\circ} 1$ which includes berths 1 and 2, both for commercial ships, plus one area for fishing boats service; Terminal $\mathrm{N}^{\circ} 2$ which includes berths 3 and 4, both for commercial ships. In year 2000 the operation of the Terminal $\mathrm{N}^{\circ} 2$ was given in concession to "Iquique Terminal Internacional S.A." (hereinafter ITI), which operates under a monooperator mode unlike EPI that operates under a multi-operator mode. In addition, EPI provides a service of a "logistic center" which is a complementary business to the port business.

According to operational statistics provided by EPI in the year 2013, 76.6\% of the cargo in Iquique Port corresponded to containerized cargo, most of which were handled by ITI, because EPI have not invested in container transfer equipment for Terminal $\mathrm{N}^{\circ} 1$. In Table 5 and Table 6 is displayed the evolution of freight transfer by each terminal from 2008 through 2011 (EPI 2013). This has great significance in the port operation of Iquique in the aftermath of the earthquake on April 1, 2014. Because of the disaster the Terminal $\mathrm{N}^{\circ} 1$ was seriously damaged; however, the port could resume their compliance with the requirements of its customers operations by fully mobilizing cargo handling capacity of Terminal $\mathrm{N}^{\circ} 2$.

Leaving aside the containerized cargo, the main products transshipped in Iquique Port includes copper, fishmeal, fish oil, sulfur and vehicles (EPI 2013). The vehicles are the only major imported cargo.

According to EPI's statistics, the imported cargo at the port in the last 5 years reaches on average to $58 \%$ among the port throughput. Most of the imported cargos are containerized, however, several consignees represents only $1 \%$ or less of total imports. This is because of ZOFRI, which gathers several small wholesale businesses; from where $26 \%$ of the total of the imported products are sold primarily to customers in Bolivia (ZOFRI 2013). As a consequence of this, most of the containers that leave the port are directed toward storage areas in ZOFRI. 
Table 5 Freight transfer [ton], Terminal $N^{\circ} 1$, from 2008 through 2011. (Modified from EPI (2013)).

\begin{tabular}{|l|l|l|l|l|}
\hline Type of freight & $\mathbf{2 0 0 8}$ & $\mathbf{2 0 0 9}$ & $\mathbf{2 0 1 0}$ & $\mathbf{2 0 1 1}$ \\
\hline Break bulk & 213,408 & 162,522 & 209,749 & 279,728 \\
\hline Containerized & 665,097 & 381,476 & 288,689 & 99,792 \\
\hline Bulk & 28,865 & 28,417 & 70,051 & 197,878 \\
\hline Total & 90,737 & 572,415 & 568,489 & 577,398 \\
\hline
\end{tabular}

Table 6 Freight transfer [x1000 ton], Terminal $N^{\circ} 2$, from 2008 through 2011. (Modified from EPI (2013))

\begin{tabular}{|l|l|l|l|l|}
\hline Type of freight & $\mathbf{2 0 0 8}$ & $\mathbf{2 0 0 9}$ & $\mathbf{2 0 1 0}$ & $\mathbf{2 0 1 1}$ \\
\hline Break bulk & 324.4 & 24.6 & 26.9 & 248.0 \\
\hline Containerized & $1,585.0$ & $1,340.4$ & $1,802.0$ & $1,801.1$ \\
\hline Bulk & 201.6 & 75.0 & 90.2 & 80.0 \\
\hline Total & $2,111.0$ & $1,661.0$ & $2,160.8$ & $2,129.1$ \\
\hline
\end{tabular}

Furthermore, and consistent with Table 6, the main clients for exports are mining companies operating in the region as well as fisheries. Note that this means that most of the containers arriving to Iquique with cargo must leave empty to the center of the country where they will be used (Caselli et al. 2014), so empty containers will stay at the port for some time.

Figure 15 illustrates different stakeholders of the port besides Chilean Government and organisms displayed in Figure 4, which may provide the basic context of the stakeholders in port of Iquique.

\subsection{Disaster Response in the Iquique port}

According to the Chilean law, all ports must develop emergency response plans, which include responding actions against earthquake and tsunami disasters. Each plan states the actions to be taken in order to ensure safety of the workforce and the liabilities to return to the port for taking preliminary actions. However, none of the plans include neither possible course of actions nor scenarios to return to normal operation, which is expected to be addressed with the BCP/BCM.

In any case, the response plans of the port must stay in line with the National Civil Protection System mentioned on chapter 2.

\subsection{BIA discussion in Iquique port community}

Through discussions among the Iquique Port community and SATREPS Chile researchers, operations of multi-purpose terminals at the sites 1 and 2, and container terminals at the sites 3 and 4 are identified as the core businesses of port; these discussions were guided through the use of worksheet system shown in Table 2, in Figure 16 is possible to observe the criteria used to make this selection. 


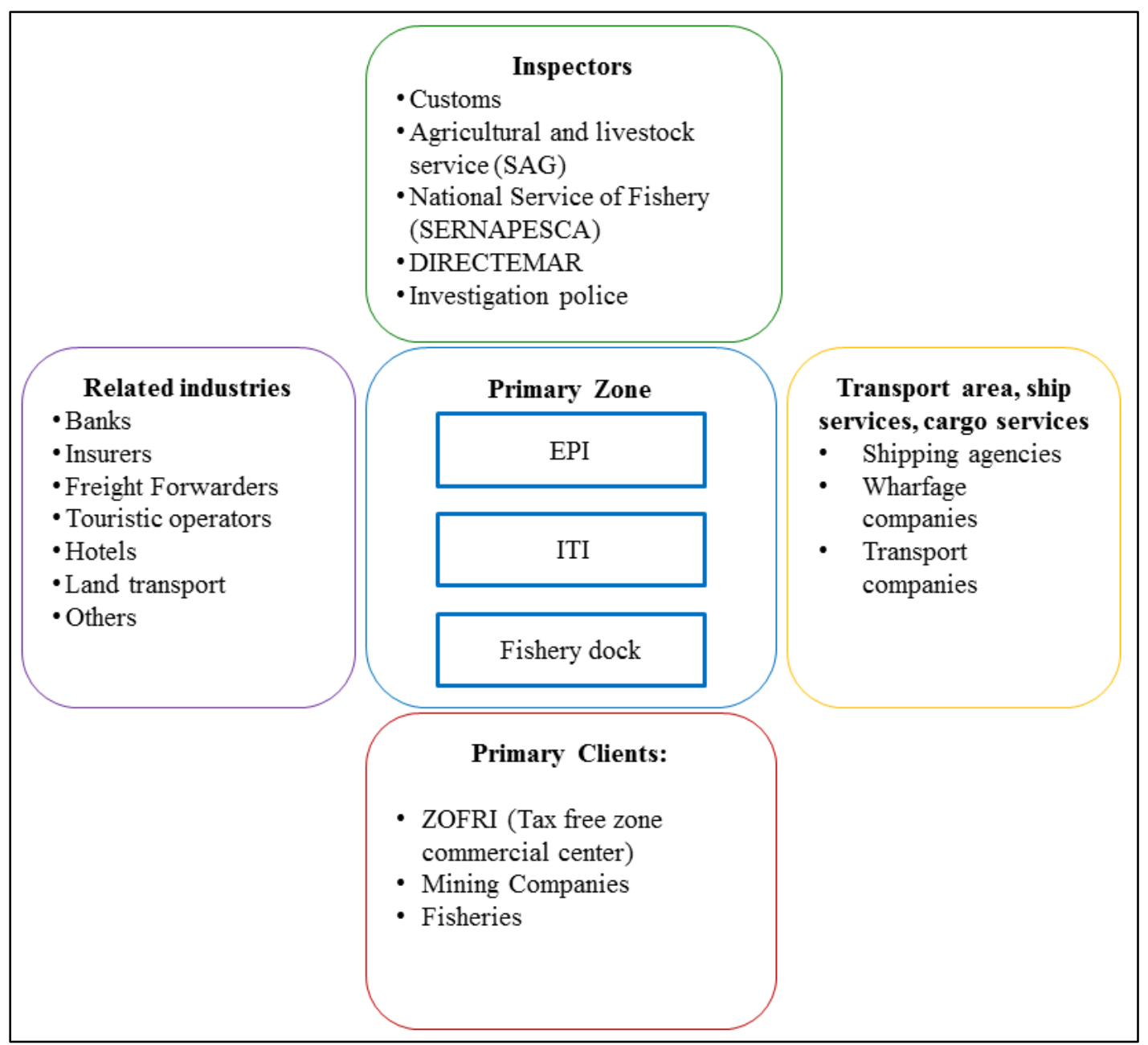

Figure 15 Iquique Port stakeholders general view

However, the sites 1 and 2 were completely demolished by the subsequent earthquake on April 1, 2014; this fact is properly reflected in the BCP of the port. It is noted that the vulnerability of site 1 and 2 had been detected through remarks of some participants during the BIA discussion process in Iquique; this shows one of the benefits of applying a participative methodology for the BIA and RA to prepare $\mathrm{BCP}$, others are mentioned bellow.

Following with the methodology of Figure 5, core business activities were identified and modeled through business flow analysis method, shown in Figure 17 with letters from A to F. Particular attention should be paid to the fact that activities of Emergency and Relief Logistic (ERL) were included in the business flow diagram, even though they are not activities of the core businesses; this was done in this way because they are very important for the support of the local community. 


\begin{tabular}{|c|c|c|c|c|c|}
\hline \multicolumn{2}{|r|}{ Selection policy } & \multicolumn{4}{|c|}{ Rating } \\
\hline Criteria & Specific impacts/risks of lossing business. & $\begin{array}{l}\text { Container } \\
\text { terminal } \\
\text { operation }\end{array}$ & $\begin{array}{l}\text { Multi- } \\
\text { purpose } \\
\text { terminal } \\
\text { operation }\end{array}$ & $\begin{array}{l}\text { Logistics } \\
\text { center } \\
\text { operation }\end{array}$ & $\begin{array}{c}\text { Fishing port } \\
\text { operation }\end{array}$ \\
\hline $\begin{array}{l}\text { Sustainable development } \\
\text { of the local economy }\end{array}$ & $\begin{array}{l}\text { Negative impact on the growth of local industry } \\
\text { including business in } \mathrm{ZOFI} \text {, and fishery and mining. }\end{array}$ & A & A & A & B \\
\hline $\begin{array}{l}\text { Livelihood of the local } \\
\text { people }\end{array}$ & $\begin{array}{l}\text { Negative impact on the people's livelihood due to } \\
\text { supply disruption of consumer goods. }\end{array}$ & A & B & C & B \\
\hline $\begin{array}{l}\text { Undertaking efficient and } \\
\text { effective ERL. }\end{array}$ & $\begin{array}{l}\text { Risks to fail to meet requirements for the } \\
\text { emergency relief logistics by sea. }\end{array}$ & A & A & $\mathbf{C}$ & $\mathbf{C}$ \\
\hline $\begin{array}{l}\text { Port competitiveness and } \\
\text { market share }\end{array}$ & $\begin{array}{l}\text { Risks of the terminals to lose out in competition } \\
\text { with the rival ports and/or competing land surface } \\
\text { transportations. }\end{array}$ & A & A & A & C \\
\hline $\begin{array}{l}\text { Financial soundness of } \\
\text { port operation }\end{array}$ & $\begin{array}{l}\text { Risks of the port operating entities to lose incomes } \\
\text { and profit. }\end{array}$ & A & A & A & C \\
\hline Loss/fine & $\begin{array}{l}\text { Risks of the port operating entities to incur penalty } \\
\text { or compensation for port service disruption. }\end{array}$ & B & B & C & C \\
\hline & Total score & 11 & 10 & 6 & 2 \\
\hline Incl & dusion or exclusion in BCP & $\begin{array}{l}\text { Include } \\
\text { /exclude }\end{array}$ & $\begin{array}{l}\text { Include } \\
\text { /exciude }\end{array}$ & $\begin{array}{l}\text { Include } \\
\text { exclude }\end{array}$ & $\begin{array}{l}\text { Include } \\
\text { exclude }\end{array}$ \\
\hline
\end{tabular}

Figure 16 Screening core business of Iquique Port

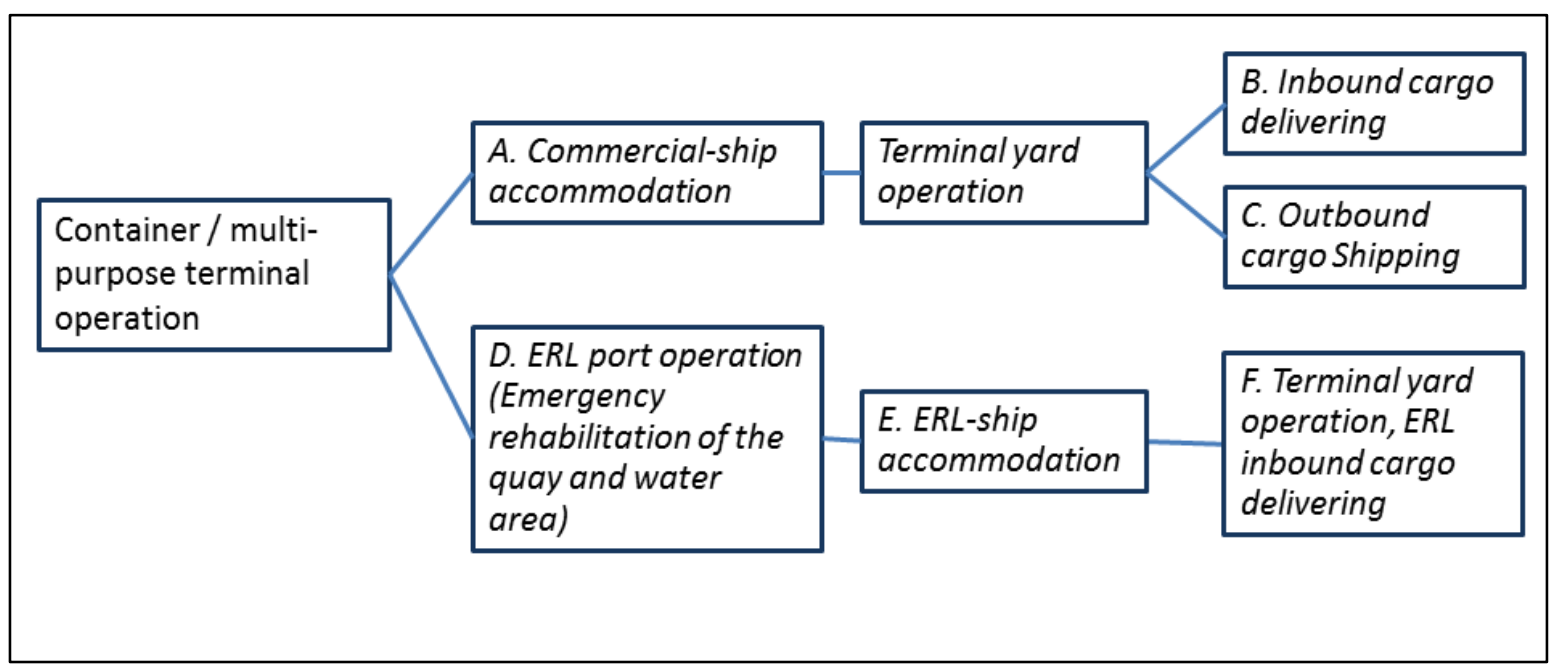

Figure 17 Breakdown of the core business structure

For the modeling of the activities, a series of workshop meetings were carried out with different members of the port community, including a union of transporters, as well as with members of the emergency management community such as staff from ONEMI. The modeling of ERL activities, identified as D, E and F in Figure 17, were discussed under participation of ONEMI. This process 
allowed participants to share their knowledge and information beyond port and logistic operations, including issues regarding the participation and responsibilities of the different organizations after a disaster. After the series of discussions, strong ties and links were established among the participants, which proved to be useful at the time of 2014 earthquake (Caselli et al. 2014); according to the regional Director of Port Works of Tarapaca as well as to the Chief of the Engineering Department of EPI, the discussions carried out before the earthquake were very useful and helped to restart the operations of the port in only 3 days. In order to create a participative environment in the workshops, it was proved that leadership and coordination function is necessary to facilitate, and maintain the focus and goal of the discussion, without constraining the contributions of the participants. This role was undertaken by the WG4b members of SATREPS Chile project.

It's worth noting that somebody related to the port system should take this role. On the one hand the "continuity activities" should be considered as permanent, applying the continual improvement principles. So it is necessary that somebody within the port community be the formal leader to have a sense of representativeness. On the other hand, the links and ties among the organizations participants of the port community helps to bring them closer to achieve some of the principles included in the Sendai Framework for Disaster Risk Reduction 2015-2030 by UNISDR (the United Nations Office for Disaster Risk Reduction). Specifically, they may strengthening disaster risk governance to manage disaster risk, through a "clear vision, plans, competence, guidance and coordination within and across sectors as well as participation of relevant stakeholders" (United Nations 2015, p. 12).

Nevertheless, at final stages of the BIA discussion, it was confirmed by the workshop members that the activities of ERL were not part of business activities, thus were not included in the worksheets of the BIA, by considering that the goal of the BCP is to ensure fast recovery of the port operations in accordance with customers' requirements. The information obtained is of tremendous value for the phase of continuity strategies preparation, specifically for the early stages of recovery.

This process of discussion also proved the benefits of having a team dedicated to BCP development. In the case of Iquique this team is formed by professionals of EPI's engineering department. Currently the ISO 22301 does not require the establishment of a continuity team, which was part of the BS25999 published on $2006^{6}$. However this team indeed facilitated the process of analysis and data collection, as well as the communications with the concessionaire and with departments within the company. Also, the establishment of this team has the benefit of allowing the management of an emergency, in accordance with the ISO 22320 standard. Because the port system is indeed made up of various organizations they should have the ability to share a common approach beyond their boundaries (a multi-organizational one) to allow that cooperation, coordination and exchange of information are carried out effectively and efficiently. Using the worksheets allows having a simple tool to establish the relations among resources and its relevance on the core businesses, and facilitating the understanding for the different actors who are not only the permanent team members but are also all concerned.

\subsection{Suggestions, implications and recommendations}

The authors reviewed in this chapter in-site applications and discussions in terms of the proposed BCP preparation procedure, in particular, by focusing on techniques for BIA implementation. Intensive discussions were undertaken, and the awareness about disasters and methodologies are well shared among SATREPS Chile WG4b and Iquique port community members. Implications, suggestions, and recommendations obtained through the BIA implementation are summarized as the followings:

\footnotetext{
${ }^{6}$ British Standard 25999-1:2006, Code of practice for business continuity management British Standard 25991-2:2007, Specifications
} 
i. Business flow analysis by mobilizing IDEF0 technique may properly assist port community in identifying and shearing port business process details and operational resources based on their respective views, information and expertizes.

ii. The Worksheet system may help define port core business, evaluate MTPD and recognize interdependency among the resources precisely. Worksheets are also available as effective and traceable records for maintaining and reviewing $\mathrm{BCP}$.

iii. Workshop meetings not only facilitate BIA discussions but also encourage active participation of the port community in Iquique.

iv. Leadership is definitely needed to activate and properly summarize the workshop discussion. In this view, contributions extended by SATREPS Chile members from University of Valparaiso are notable.

v. Implementing a continuity team within the Port, with members of different departments, may facilitate development and maintenance of BCP.

vi. Intensive discussions on RA should be continued for completing BCP analysis and appraisal. The authors recommend encouraging further involvement and commitment of Chilean Government, in particular the Ministry of Public Works and the Ministry of Transportation and Telecommunication.

\section{CONCLUSIONS}

Because of it geomorphological characteristics, Chile is prone to disasters by earthquakes and tsunamis, which can cause serious damage on ports as well. Given that ports are of high importance to the Chilean economy, it is necessary to explore ways to accelerate recovery operations, to manage their continuity. From this view point the proposed technique for undertaking the BIA proved to be useful to analyze the port business work flow structure in the Port of Iquique. Suggested BIA process comprising IDEF0 method and the worksheet system are transparent enough to be followed not only by port people, but people from other areas as well. At the same time, the benefits of undertaking workshop discussions with people from the community include securing proper participation of people involved in some way in post disaster activities, and creating strong ties among them. The methodology and techniques presented in this paper are expected to facilitate effective and efficient brainstorming among port communities for detecting vulnerabilities of port logistics functions, some unknown activities, weak points of administrative procedures and regulatory frameworks, and further increasing awareness of the potentiality of joint works.

For the case of the Port of Iquique, there has been a lot of interest among the port site managers to participate in this project, and the BIA process has successfully demonstrated its usefulness in particular after the earthquake of April 1, 2014. However, every Chilean port should implement the BIA procedure for preparing BCP. Further involvement of MTT is vital in order to guarantee the needed leadership, in order to convince all port players to participate in the BCM preparation. In this regard, it is strongly recommended that a clear policy regarding the implementation of BCP/BCM should be established at least in state ports as soon as possible.

At the end, the final goal is to increase the recovery and resiliency of the entire community and this kind of work has proven to be useful to achieve that goal.

\section{REFERENCES}

Agosin, M. (1999) Comercio y crecimiento en Chile (Growth and commerce in Chile). Revista de la CEPAL, Issue 68, pp. 79-100 (in Spanish)

Akakura, Y., Hemmi, M., Ono, K., Ishihara, M., and Fukumoto, M. (2014) An estimation of recovery 
curve of maritime containerized cargo demand after large-scale earthquake and tsunami, Journal of Japan Society of Civil Engineers, Division D3, Vol.70, No.5, I_689-I_699.

Bergoeing, R., Micco, A. ,and Andrea, R. (2011) Una mirada al auge exportador chileno (A look at the Chilean export boom). Revista de la CEPAL, Issue 105, pp. 95-112 (in spanish)

Banco Central de Chile (2010) Informe Económico, Cuentas Nacionales de Chile 2003 - 2010 (Economic Report, National Accounts of Chile 2003 - 2010). Santiago (in spanish)

Banco Central de Chile (n.d.) Indicadores de Comercio Exterior, Cuarto Trimestre 2013 (Trade Indicators, Fourth Quarte 2013). Santiago(in spanish)

Botha, J., and Von Solms, R. (2004). A cyclic approach to business continuity planning. Information Management \& Computer Security, 12(4), 328 - 337

CAMPORT (2013) Memoria anual $N^{\circ} 69$ (Annual report $N^{\circ} 69$ ). Cámara Marítima y Portuaria de Chile A. G., Valparaíso. http://www.camport.cl/memoria2013final.pdf (in sapnish)

Caselli, F., Beale, M., and Reyes, M. (2014) Impact of the recent earthquake and tsunami on Chilean port. S. Iai (Ed.), Geotechnics for Catastrophic Flooding Events, pp. 207-215. CRC Press. Leiden

Carrillo, I., and Santander, A. (2005) Modernización portuaria en Chile (Port modernization in Chile). Síntesis tecnológica, 2 (2), PP. 63-68. (in spanish)

CEPAL (2010) Terremoto en Chile. Una primera mirada al 10 de marzo de 2010 (Earthquake in Chle: A first look at March 10, 2010), Santiago de Chile: Naciones Unidas (in spanish)

Chao, A., Sepúlveda, I., Liu, P. (2010) Tsunami source and its validation of the 2014 Iquique, Chile, earthquake. Geophysical Research Letters.

EPI (2013) Request of report on competition terms to tender port concession of Terminal $N^{\circ} 1$ of Iquique Port to the Court for Defense of Free Competition. http://www.licitacionpuertoiquique.com/docs/consultaTDLCEPI.pdf

Goldfinger, C., Ikeda, Y., Yeats, R. and Ren, J. (2013) Superquakes and Supercycles. Seismological Research Letters, p. Vol. 84 Nr.1.

Hayes, G., Herman, M., Barnhart, W., Furlong, K., Riquelme, S., Benz, H., Bergman, E., Barrientos, S., Earle, P., and Samsonov, S. (2014) Continuing megathrust earthquake potential in Chile after the 2014. Iquique earthquake. Nature.

I. Municipalidad de Iquique, (2011) D.A.425 - Plan de Respuesta Comunal (D.A.425 - Municipal Response Plan). (in spanish)

INE (2010) Informe Económico Regional, abril - junio 2010 (Regional Economic Report, April-June 2010). Instituto Nacional de Estadística de Chile, Santiago. (in spanish)

ISO (2012) ISO 22301, Societal security - Business Continuity Managemen Systems - Requirements. First ed. Switzerland: ISO

Komatsu, R., Hayashi H., Ohara, M., Samejima, R., Tamase, M., Toyoshima, K., Kimura, R., and Suzuki, S. (2013) Developing business continuity plan for water treatment facilities based on the business impact analysis and the risk assessment of tsunami caused by the theoretically maximum Nankai Trough Earthquake - Through the case study at Osaka Municipal Waterworks Bureau -, Journal of Natural Disaster Science. JSNDS 32- 2, pp.183-205.

Kon, M. (2009) Manual for practicians on preparing business continuity plan, Ohomu Express Co. ltd

Lin, C.-S., Kao, S., and Chen, L.-S. (2012) A Proactive Operational Framework for Business Continuity in the Semiconductor Industry. Quality and Reliability Engineering International, 28 (3), pp. 307-320. 
Lomnitz, C. (1970) Major earthquakes and tsunamis in Chile during the period 1535 to 1955. Geologische Rundschau, v. 59, pp. 938-960.

MLIT (2012) General report of the East Japan Great Earthquake. Ministry of Land, Infrastructure, transport and tourism. (in Japanese)

MTT (2014) Plan Nacional de Desarrollo Portuario (National Port Development Plan). Ministerio de Transporte y Telecomunicaciones, Gobierno de Chile: Santiago. (in spanish)

Ministerio de Relaciones Exteriores (2009) 20 años de la Evolución del Comercio Exterior chileno (20 years of evolution of the Chilean foreign trade). Departamento de Estudios e Información de la Dirección General de Relaciones Económicas Internacionales del Ministerio de Relaciones Exteriores de Chile: Santiago. (in sapnish)

ONEMI (2012) Plan de Respuesta a Emergencias de la Región de Tarapacá (Emergency Response Plan for the Region of Tarapacá). Intendencia Regional de Tarapacá: Iquique. (in spanish)

Ono, K., Takino, Y., and Akakura, Y. (2014) Introducing Business Impact Analysis into Business Continuity Management for Port Logistics. Proceedings of Infrastructure Planning Vol.48, Committee of Infrastructure Planning and Management, JSCE

PNUD (2012a) Análisis de Riesgos de Desastres en Chile (Disaster Risk Analysis in Chile). United Nations Development Programme: Santiago de Chile. (in Spanish)

PNUD (2012b) Guía Participativa de Orientaciones de Respuesta frente a Emergencias de TerremotoTsunami a partir de la Experiencia de Talcahuano, Chile (Participatory Guide on Orientations for Emergency Response to Earthquake-Tsunami based on the experience of Talcahuano, Chile). United Nations Development Programme: Santiago. (in Spanish)

Reyes, M., and Miura F. (2013) A Proposal of Tsunami Risk Assessment Method for Iquique City, Chile. National Graduate Institute for Policy Studies (GRIPS): Tokyo.

SEP (2006) Modernización portuaria en Chile, Bitácora 1998 - 2005 (Port modernization in Chile, Logbook 1998 - 2005). Dirección de Empresas Portuarias, Sistema de Empresas SEP: Santiago. (in Spanish)

United Nations. (2015). Sendai Framework for Disaster Risk Reduction 2015-2030. Revised January, 2016, from The United Nations Office for Disaster Risk Reduction (UNISDR): http://www.unisdr.org/we/inform/publications/43291

Winckler, P., Reyes, M. and Sepúlveda, I. (2010) El Tsunami del 27-02-2010 en isla Robinson Crusoe, Archipiélago de Juan Fernández (The Tsunami of February 27, 2010 in Robinson Crusoe Island, Juan Fernández Archipelago). Universidad de Valparaíso: Valparaíso. (in Spanish)

ZOFRI, 2012. Memoria anual ZOFRI SA (Yearbook Free Tax Zone of Iquique). ZOFRI: Iquique (in Spanish)

ZOFRI, 2013. Boletín estadístico Enero - Diciembre 2013 (Statistical bulletin January - December 2013). ZOFRI: Iquique (in Spanish). 